\title{
Continental pollution in the western Mediterranean basin: vertical profiles of aerosol and trace gases measured over the sea during TRAQA 2012 and SAFMED 2013
}

\author{
C. Di Biagio ${ }^{1}$, L. Doppler ${ }^{2,3,4}$, C. Gaimoz ${ }^{1}$, N. Grand ${ }^{1}$, G. Ancellet ${ }^{2}$, J.-C. Raut ${ }^{2}$, M. Beekmann ${ }^{1}$, A. Borbon ${ }^{1}$, \\ K. Sartelet ${ }^{5}$, J.-L. Attié ${ }^{6,7}$, F. Ravetta ${ }^{2}$, and P. Formenti ${ }^{1}$ \\ ${ }^{1}$ LISA, UMR CNRS 7583, Université Paris Est Créteil et Université Paris Diderot, Institut Pierre Simon Laplace, \\ Créteil, France \\ ${ }^{2}$ Sorbonne Universités, UPMC Univ. Paris 06, Université Versailles St-Quentin, CNRS/INSU, LATMOS-IPSL, Paris, France \\ ${ }^{3}$ Freie Universität Berlin, Berlin, Germany \\ ${ }^{4}$ Deutscher Wetterdienst, Meteorological Observatory Lindenberg, Lindenberg, Germany \\ ${ }^{5}$ CEREA, Joint Laboratory École des Ponts ParisTech - EDF R \& D, Université Paris-Est, 77455 Marne la Vallée, France \\ ${ }^{6}$ Laboratoire d'Aérologie, University of Toulouse, UMR 5560 CNRS, Toulouse, France \\ ${ }^{7}$ CNRM GAME, UMR 3589 CNRS, Meteo-France, Toulouse, France
}

Correspondence to: C. Di Biagio (claudia.dibiagio@lisa.u-pec.fr)

Received: 1 March 2015 - Published in Atmos. Chem. Phys. Discuss.: 18 March 2015

Revised: 17 July 2015 - Accepted: 21 July 2015 - Published: 27 August 2015

\begin{abstract}
In this study we present airborne observations of aerosol and trace gases obtained over the sea in the western Mediterranean basin during the TRAQA (TRansport and Air QuAlity) and SAFMED (Secondary Aerosol Formation in the MEDiterranean) campaigns in summer 2012 and 2013. A total of 23 vertical profiles were measured up to $5000 \mathrm{~m}$ above sea level over an extended area $\left(40-45^{\circ} \mathrm{N}\right.$ and $2^{\circ} \mathrm{W}-12^{\circ} \mathrm{E}$ ) including the Gulf of Genoa, southern France, the Gulf of Lion, and the Spanish coast. During TRAQA and SAFMED the study area experienced a wide range of meteorological conditions which favoured pollution export from different sources located around the basin. Also, several events of dust outflows were measured during the campaigns. Observations from the present study show that continental pollution largely affects the western Mediterranean both close to coastal regions and in the open sea as far as $\sim 250 \mathrm{~km}$ from the coastline. The measured aerosol scattering coefficient varies between $\sim 20$ and $120 \mathrm{Mm}^{-1}$, while carbon monoxide $(\mathrm{CO})$ and ozone $\left(\mathrm{O}_{3}\right)$ mixing ratios are in the range of $60-165$ and $30-85$ ppbv, respectively. Pollution reaches $3000-4000 \mathrm{~m}$ in altitude and presents a very complex and highly stratified structure characterized by fresh and aged layers both in the boundary layer and in the free troposphere. Within pollution plumes the measured particle con-
\end{abstract}

centration in the Aitken $(0.004-0.1 \mu \mathrm{m})$ and accumulation $(0.1-1.0 \mu \mathrm{m})$ modes is between $\sim 30$ and $5000-6000 \mathrm{scm}^{-3}$ (standard $\mathrm{cm}^{-3}$ ), which is comparable to the aerosol concentration measured in continental areas under pollution conditions. Additionally, our measurements indicate the presence of highly concentrated Aitken layers (10000-15000 scm${ }^{-3}$ ) observed both close to the surface and in the free troposphere, possibly linked to the influence of new particle formation (NPF) episodes over the basin.

\section{Introduction}

Atmospheric aerosols play an important role on climate through their participation in several chemical, dynamical, and radiative processes. At present, large uncertainties still persist in the estimation of the aerosol direct and indirect effects mainly due to the difficulty of fully characterising their spatial and vertical distribution and properties (Boucher et al., 2013).

The Mediterranean region is a complex area where atmospheric aerosols of different origins and types may be found (Pace et al., 2006; Kallos et al., 2007; Gkikas et al., 2012). 
High levels of anthropogenic aerosol particles and pollutants are measured in the Mediterranean (Lelieveld et al., 2002), which is also indicated as one of the main hot spots for air quality issues (Monks et al., 2009).

The north-western part of the Mediterranean basin, due to its proximity to highly polluted industrialised areas (such as the Po Valley in northern Italy and the Fos/Berre in southern France) and large coastal cities (Barcelona, Genoa, Marseilles, Nice, and Valencia), is frequently affected by continental outflows and severe pollution episodes (Mallet et al., 2005; Pérez et al., 2008; Pey et al., 2010). The strength of these episodes is particularly intense during summer when stable meteorological conditions and the high level of insolation promote photochemical reactions and the build-up of ozone and other pollutants (e.g. Millán et al., 2000).

A number of studies have investigated the dynamics of pollution export over the western basin with the aim of characterising the impact of anthropogenic emissions over this region. Most of these studies have been conducted in continental coastal areas and provide information on the vertical distribution of aerosols and their properties mainly close to local pollution sources. They include ground-based observations with lidars (Soriano et al., 2001; Pérez et al., 2004; Ancellet and Ravetta, 2005), and airborne campaigns, such as MECAPIP (MEso-meteorological Cycles of Air Pollution in the Iberian Peninsula) and RACAPMA (RegionAl Cycles of Air Pollution in the west central Mediterranean Area) in coastal Spain (Millán et al., 1996, 1997), and ESCOMPTE (Experience sur Site pour Contraindre les Modeles de Pollution atmospherique et de Transport d'Emissions) in southern France (Drobinski et al., 2007). The results of these studies have highlighted the important role of pollution in modulating the atmospheric composition in this part of the basin and the high variability of the aerosol distribution and properties in relation to different export conditions (Flamant and Pelon, 1996; Soriano et al., 2001; Mallet et al., 2005). In particular, the interaction between synoptic circulation and local dynamics, such as orography and sea breezes, has been shown to strongly impact the vertical distribution, layering, and aging of particles along coastal regions (e.g. Millan et al., 1997; Gangoiti et al., 2001; Pérez et al., 2004; Velchev et al., 2011).

The capability of reproducing this complexity by air quality models represents a real challenge (Jimenez et al., 2006; Jiménez-Guerrero et al., 2008), and experimental observations gives a fundamental support to test the performances of the model outputs over the western Mediterranean environment.

The large set of observations conducted in the last few decades in the western Mediterranean has permitted mostly to characterise the dynamics and processes of pollution export in the surroundings of the basin. However, at the present time we lack an extensive representation of the mean load, distribution, and physico-chemical and optical properties of the atmospheric aerosols, and the trace gases distribution, in the whole region, in particular over the remote sea. In addi- tion, there is a significant lack of observations over some key areas, as for example the Gulf of Genoa, directly under the influence of the outflow from the highly polluted Po Valley (Velchev et al., 2011).

In this study we present vertical profile measurements of aerosols and trace gases acquired during 24 scientific flights performed with the ATR-42 French research aircraft during the TRAQA (TRansport and Air QuAlity) and SAFMED (Secondary Aerosol Formation in the MEDiterranean) campaigns in summer 2012 and 2013 in the framework of the Chemistry-Aerosol Mediterranean Experiment (CHARMEX, https://charmex.lsce.ipsl.fr/). The TRAQA and SAFMED flights explored an extended region of the western Mediterranean basin between $40-45^{\circ} \mathrm{N}$ and $2^{\circ} \mathrm{W}-12^{\circ} \mathrm{E}$ including the Gulf of Genoa, southern France, the Gulf of Lion, and the Spanish coast. Measurements were performed over the sea at various distances from the coastline with lidar and in situ instruments. During TRAQA and SAFMED the western basin was under diverse synoptic conditions which led to the occurrence of different pollution export regimes (mistral/tramontane events, outflow from the Po Valley and the Iberian Peninsula) and allowed for the sampling of atmospheric aerosols of different origins and types.

The main objective of the present work is to provide observations of the vertical distribution of aerosols and trace gases related to the export of anthropogenic pollution at the regional scale of the western Mediterranean basin. The detailed knowledge of the vertical structure of the atmosphere is very important to understand the impact of continental pollution over the basin.

The paper is organised as follows: in Sects. 2, 3, and 4 we describe the flight trajectories and strategy during TRAQA and SAFMED, the in situ measurements carried out on board the ATR-42 aircraft, and the meteorological conditions observed during the campaigns. In Sect. 5 we present the results. The aerosol and trace gases vertical profiles are shown in Sect. 5.1 and 5.2. Section 5.3 is dedicated to analyse the variability of the pollution plume composition and atmospheric structure also in relation to the different outflow conditions. Airborne measurements in the presence of layers with high concentrations of fine particles are discussed in Sect. 5.4. The main conclusions are reported in Sect. 6.

\section{Overview of flights}

Figure 1 shows the trajectories of the flights performed during the TRAQA (20 June-13 July 2012) and the SAFMED (24 July-1 August 2013) campaigns. Research flights were performed with the SAFIRE (Service des Avions Français Instruments pour la Recherche en Environnement, http:// www.safire.fr/) tropospheric aircraft ATR-42. The aircraft has a maximum flight time of $4 \mathrm{~h}$. The flight altitude ranges between a minimum of $\sim 60 \mathrm{~m}$ and a maximum of $\sim 5000 \mathrm{~m}$ above sea level (a.s.1.). The aircraft was based in 


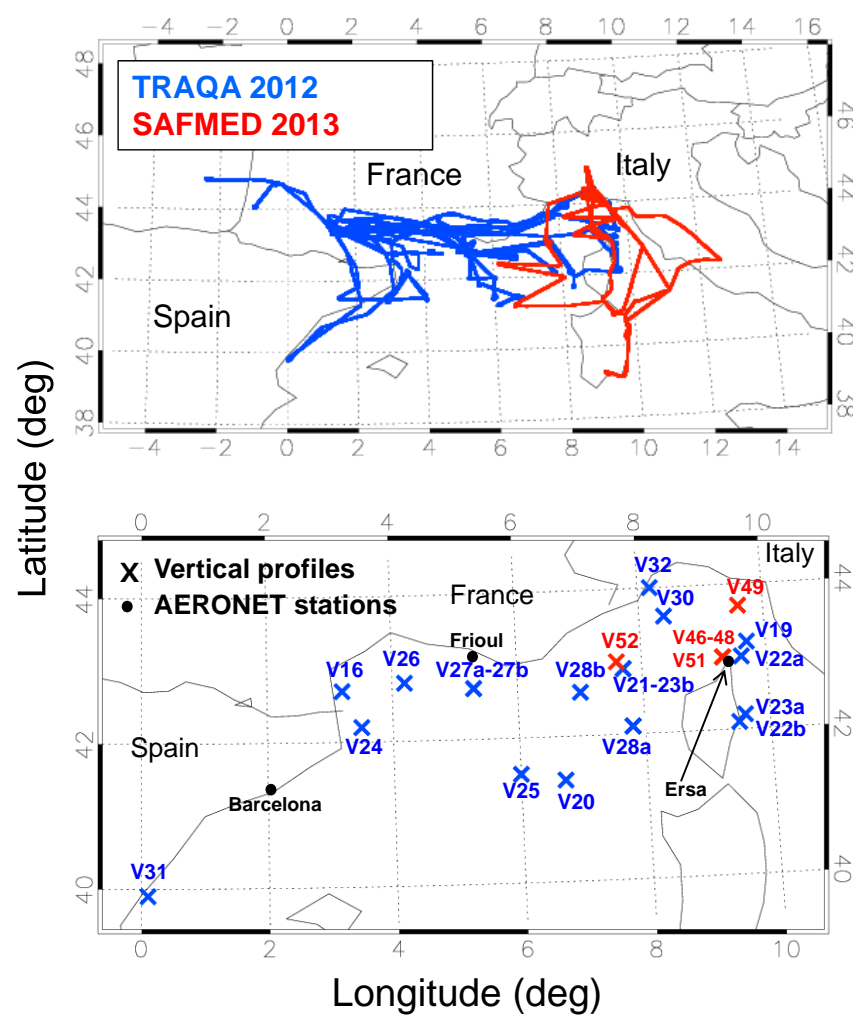

Figure 1. Upper panel: flight trajectories of the TRAQA (20 June13 July 2012) and the SAFMED (24 July-1 August 2013) campaigns. The aircraft was based in Toulouse, France $\left(43^{\circ} 36^{\prime} \mathrm{N}\right.$, $\left.1^{\circ} 26^{\prime} \mathrm{E}\right)$, during TRAQA and in Genoa, Italy $\left(44^{\circ} 24^{\prime} \mathrm{N}, 8^{\circ} 55^{\prime} \mathrm{E}\right)$, during SAFMED. Lower panel: detail on the investigated area and geographical position of the different vertical soundings analysed in this paper. The position of the three AERONET stations of Barcelona, Frioul, and Ersa considered in this study is also shown.

Toulouse $\left(43^{\circ} 36^{\prime} \mathrm{N}, 1^{\circ} 26^{\prime} \mathrm{E}\right.$, France) during TRAQA and in Genoa ( $44^{\circ} 24^{\prime} \mathrm{N}, 8^{\circ} 55^{\prime} \mathrm{E}$, Italy) during SAFMED. Twentyfour flights which recorded a total of $\sim 75 \mathrm{~h}$ of data were flown. Seventeen of the 24 flights presented in the paper were performed during TRAQA (flight numbers V16 to V32) and 7 during SAFMED (V46 to V52). All flights were carried out during daytime, when light-induced chemistry favours the pollution levels. Most often two flights per day, with intermediate stops in different airports in southern France, Corsica, and Sardinia, were performed. The majority of flights were over the sea, with some exceptions investigating inland areas in southern France and central Italy. Information concerning the TRAQA and SAFMED flights is summarised in Table 1.

The general flight strategy consisted of plane flights with lidar observations and vertical ascents/descents to sound the vertical atmospheric column (from $\sim 60-100 \mathrm{~m}$ to 3000 $5000 \mathrm{~m}$ a.s.l.) and identify main meteorological and aerosol features, followed by straight levelled runs (SLRs) within the detected aerosol layers. In this study we focus on vertical profile data. A total of 23 profiles were acquired in $20-30 \mathrm{~min}$ each by performing a spiral trajectory $\sim 10-20 \mathrm{~km}$ wide. Figure 1 also identifies the geographical position of each sounding. As shown in Fig. 1 the profiles were performed at different distances from the coastline, from a minimum of $\sim 5$ $10 \mathrm{~km}$ for V31 and V32 to more than $\sim 250 \mathrm{~km}$ for V20 and $\mathrm{V} 25$, and covered almost all the different sectors of the western basin.

\section{Measurements and methods}

The basic equipment of the ATR-42 aircraft includes sensors for the measurements of meteorological parameters (pressure, temperature, relative humidity, wind components), radiative fluxes (down- and up-welling shortwave and longwave radiation), and carbon monoxide $(\mathrm{CO})$ and ozone $\left(\mathrm{O}_{3}\right)$ mixing ratios.

Aerosol sampling was performed using the AVIRAD system (Formenti et al., 2011). AVIRAD is an iso-axial and iso-kinetic inlet which, at the normal cruise speed of the ATR-42 $\left(\sim 93 \mathrm{~m} \mathrm{~s}^{-1}\right)$, samples air at a volumetric flow of $\sim 350 \mathrm{~L} \mathrm{~min}^{-1}$. The $50 \%$ passing efficiency of the inlet was tested to be $12 \mu \mathrm{m}$ diameter. Various sampling lines depart from AVIRAD to connect to different instruments mounted inside the aircraft cabin: (i) a three-wavelength nephelometer (TSI Inc., model 3563) for the measurement of the dry particle volume total scattering $\left(\sigma_{\mathrm{s}}\right)$ and hemispherical backscattering $\left(\sigma_{\mathrm{bs}}\right)$ coefficients at 450,550 , and $700 \mathrm{~nm}$; (ii) a sevenwavelength aethalometer (Magee Sci., model AE31) for the measurement of the particle absorption coefficient $\left(\sigma_{\mathrm{a}}\right)$ at $370,470,520,590,660,880$, and $950 \mathrm{~nm}$; (iii) an optical particle spectrometer (GRIMM Inc., model 1.129) for the measurement of the particle number concentration over 32 size classes between 0.3 and $32 \mu \mathrm{m}$ in diameter; (iv) a condensation particle counter (CPC, TSI Inc., model 3775) for the measurement of the total particle number concentration in the diameter range of 0.004-3.0 $\mu \mathrm{m}$; and (v) three lines for aerosol sampling on filter membranes and a four-stage cascade impactor (Dekati Inc) to measure the bulk and sizesegregated particle composition. In addition, the ATR-42 was equipped with a passive cavity aerosol spectrometer probe (PCASP, model 100X) optical particle spectrometer for the measurement of the aerosol number concentration over 31 size classes between 0.1 and $3.0 \mu \mathrm{m}$. The PCASP was installed outside the cabin on the left side of the aircraft fuselage.

In this study we consider measurements of the (i) aerosol scattering coefficient from the nephelometer, (ii) particle concentration from the CPC and PCASP instruments (GRIMM data are not considered since they are available only below $\sim 350 \mathrm{~m}$ during TRAQA), (iii) $\mathrm{CO}$ and $\mathrm{O}_{3}$ trace gases from the MOZART analyser, and (iv) meteorological parameters from the ATR- 42 sensors. A more detailed description of the nephelometer, CPC, PCASP, and MOZART 
Table 1. Summary of information on the TRAQA and SAFMED flights.

\begin{tabular}{|c|c|c|c|c|c|c|}
\hline $\begin{array}{l}\text { Measurement } \\
\text { campaign }\end{array}$ & $\begin{array}{l}\text { Flight } \\
\text { number }\end{array}$ & Date & $\begin{array}{l}\text { Take off-landing } \\
\text { time (UTC) }\end{array}$ & $\begin{array}{l}\text { Departure- } \\
\text { arrival }\end{array}$ & $\begin{array}{l}\text { Geographic area } \\
\text { investigated }\end{array}$ & Description \\
\hline \multirow[t]{17}{*}{ TRAQA 2012} & V16 & $20 / 06 / 2012$ & $13: 12-16: 34$ & Toulouse-Toulouse & Gulf of Lion & Test flight \\
\hline & V17* & $22 / 06 / 2012$ & $09: 01-12: 54$ & Toulouse-Toulouse & $\begin{array}{l}\text { South-western France (over } \\
\text { land) and the Atlantic Ocean }\end{array}$ & Test flight, biogenic emissions. \\
\hline & V18* & $26 / 06 / 2012$ & $07: 13-09: 18$ & Toulouse-Bastia & Gulf of Genoa & $\begin{array}{l}\text { Export of pollution from northern Italy/Po Valley, } \\
\text { north-westerly winds }\end{array}$ \\
\hline & V19 & $26 / 06 / 2012$ & $10: 42-13: 46$ & Bastia-Toulouse & Gulf of Genoa & $\begin{array}{l}\text { Export of pollution from northern Italy/Po Valley, } \\
\text { north-westerly winds }\end{array}$ \\
\hline & $\mathrm{V} 20$ & $27 / 06 / 2012$ & 04:07-08:00 & Toulouse-Nimes & $\begin{array}{l}\text { Sea area south of Mar- } \\
\text { seille/Toulon }\end{array}$ & $\begin{array}{l}\text { Export of pollution during a mistral/tramontane } \\
\text { event }\end{array}$ \\
\hline & $\mathrm{V} 21$ & $27 / 06 / 2012$ & $09: 39-13: 16$ & Nimes-Toulouse & Western coast of Corsica & $\begin{array}{l}\text { Export of pollution from northern Italy/Po Valley, } \\
\text { north-westerly winds }\end{array}$ \\
\hline & $\mathrm{V} 22$ & $29 / 06 / 2012$ & $05: 13-08: 50$ & Toulouse-Bastia & Eastern coast of Corsica & Dust outbreak \\
\hline & V23 & $29 / 06 / 2012$ & $10: 13-14: 12$ & Bastia-Toulouse & $\begin{array}{l}\text { Eastern and western coasts of } \\
\text { Corsica }\end{array}$ & Dust outbreak \\
\hline & V24 & $03 / 07 / 2012$ & $13: 19-17: 12$ & Toulouse-Toulouse & $\begin{array}{l}\text { Sea area north-east of } \\
\text { Barcelona }\end{array}$ & $\begin{array}{l}\text { Export of pollution from Barcelona, westerly/south- } \\
\text { westerly winds }\end{array}$ \\
\hline & V25 & $04 / 07 / 2012$ & 07:18-10:54 & Toulouse-Toulouse & $\begin{array}{l}\text { Sea area south of Mar- } \\
\text { seille/Toulon }\end{array}$ & Following Barcelona pollution plumes \\
\hline & V26 & $04 / 07 / 2012$ & $15: 25-18: 36$ & Toulouse-Toulouse & Gulf of Lion & Following Barcelona pollution plumes \\
\hline & V27 & $06 / 07 / 2012$ & $08: 00-11.55$ & Toulouse-Toulouse & Sea area south of Marseille & $\begin{array}{l}\text { Export of pollution during a moderate mis- } \\
\text { tral/tramontane event }\end{array}$ \\
\hline & V28 & $06 / 07 / 2012$ & $14: 01-17: 45$ & Toulouse-Toulouse & Sea area south of Nice/Toulon & $\begin{array}{l}\text { Export of pollution during a moderate mis- } \\
\text { tral/tramontane event }\end{array}$ \\
\hline & $\mathrm{V} 29^{*}$ & $07 / 07 / 2012$ & $08: 19-10: 59$ & Toulouse-Nimes & Southern France (over land) & Biogenic emissions \\
\hline & V30 & $07 / 07 / 2012$ & $13: 03-17: 10$ & Nimes-Toulouse & Gulf of Genoa & $\begin{array}{l}\text { Export of pollution during a moderate mis- } \\
\text { tral/tramontane event }\end{array}$ \\
\hline & V31 & $10 / 07 / 2012$ & $13: 41-17: 21$ & Toulouse-Toulouse & Eastern coast of Spain & Characterisation of pollution near coastal sources \\
\hline & V32 & $11 / 07 / 2012$ & $11: 23-14: 48$ & Toulouse-Toulouse & $\begin{array}{l}\text { South-eastern coast of France } \\
\text { and Gulf of Genoa }\end{array}$ & Characterisation of pollution near coastal sources \\
\hline \multirow[t]{7}{*}{ SAFMED 2013} & V46 & $24 / 07 / 2013$ & $10: 34-13: 06$ & Genoa-Cagliari & $\begin{array}{l}\text { Gulf of Genoa and eastern coast } \\
\text { of Corsica and Sardinia }\end{array}$ & $\begin{array}{l}\text { Characterisation of pollution plumes in the Gulf } \\
\text { of Genoa, Corsica, and Sardinia; westerly/south- } \\
\text { westerly winds }\end{array}$ \\
\hline & V47* & $24 / 07 / 2013$ & $14: 21-16: 29$ & Cagliari-Genoa & $\begin{array}{l}\text { Eastern coast of Corsica and } \\
\text { Sardinia and Gulf of Genoa }\end{array}$ & $\begin{array}{l}\text { Characterisation of pollution plumes in the Gulf } \\
\text { of Genoa, Corsica, and Sardinia; westerly/south- } \\
\text { westerly winds }\end{array}$ \\
\hline & V48 & $25 / 07 / 2013$ & $13: 12-16: 02$ & Genoa-Ersa & Gulf of Genoa & $\begin{array}{l}\text { Characterisation of pollution in the Gulf of Genoa; } \\
\text { westerly/south-westerly winds }\end{array}$ \\
\hline & V49 & $27 / 07 / 2013$ & 11:08-13:07 & Genoa-Alghero & Central Italy (over land) & Characterisation of pollution in central Italy \\
\hline & V50* & $27 / 07 / 2013$ & $15: 33-16: 48$ & Alghero-Genoa & $\begin{array}{l}\text { Eastern coast of Corsica and } \\
\text { Gulf of Genoa }\end{array}$ & $\begin{array}{l}\text { Characterisation of pollution plumes in the Gulf } \\
\text { of Genoa, Corsica, and Sardinia; westerly/south- } \\
\text { westerly winds and dust outbreak }\end{array}$ \\
\hline & V51 & $30 / 07 / 2013$ & $13: 05-15: 50$ & Genoa-Ersa & Gulf of Genoa & $\begin{array}{l}\text { Characterisation of pollution in the Gulf of Genoa; } \\
\text { very low north/north-westerly winds }\end{array}$ \\
\hline & V52 & $01 / 08 / 2013$ & $12: 03-15: 24$ & Genoa-Alghero & Western coast of Corsica & $\begin{array}{l}\text { Characterisation of pollution in western Corsica; } \\
\text { export of pollution from northern Italy/Po Valley; } \\
\text { north-easterly winds }\end{array}$ \\
\hline
\end{tabular}

* No vertical profiles performed during these flights.

measurements and their data analysis is provided in the following sections.

The present analysis is based only on measurements obtained in cloud free conditions.

\subsection{Aerosol scattering coefficient}

A three-wavelength integrating nephelometer has been used to measure the dry particle volume total scattering $\left(\sigma_{\mathrm{s}}\right)$ coefficient at 450,550 , and $700 \mathrm{~nm}$. The sampling flow rate was $30 \mathrm{~L} \mathrm{~min}^{-1}$. Data were acquired at $6 \mathrm{~s}$ resolution during TRAQA and $1 \mathrm{~s}$ resolution during SAFMED. The instrument 
was calibrated prior to each campaign with free-particle air and $\mathrm{CO}_{2}$ as gases of low and high known scattering coefficient. Nephelometer measurements have been corrected for angular truncation and Lambertian non-idealities by applying the formulae by Anderson and Ogren (1998). The measurement uncertainty of $\sigma_{\mathrm{s}}$ is calculated taking into account for the photon counting, gas calibration, and angular corrections uncertainties (Anderson et al., 1996; Anderson and Ogren, 1998). The total uncertainty of $\sigma_{\mathrm{s}}$ is estimated to be lower than $10 \%$ at the three wavelengths.

The nephelometer measured the scattering coefficient in dry air conditions. This is due to the heating of the airflow while entering the aircraft cabin and the temperature in the cavity of the instrument. The relative humidity measured during the flights inside the nephelometer was $<25 \%$ in more than $90 \%$ of cases, with values up to $\sim 40 \%$ occasionally observed at very low altitudes $(<200 \mathrm{~m})$ over the sea surface. A possible underestimation of the scattering coefficient may thus occur in case of hygroscopic aerosols, especially under high relative humidity conditions in the atmosphere.

The particle scattering Ångström exponent $\left(\alpha_{\mathrm{s}}\right)$ has been calculated from spectral nephelometer measurements with a power-law fit of the measured scattering coefficients versus wavelength.

\subsection{Aerosol particle number concentration}

The vertical profiles of the total particle number concentration in the Aitken $\left(\mathrm{d} N_{\text {Aitken }}, 0.004-0.1 \mu \mathrm{m}\right)$, accumulation $\left(\mathrm{d} N_{\text {Acc }}, 0.1-1.0 \mu \mathrm{m}\right)$ and coarse $\left(\mathrm{d} N_{\text {Coarse }},>1.0 \mu \mathrm{m}\right)$ modes have been obtained by combining CPC and PCASP data. The CPC and the PCASP measured at a sample flow of 1.5 and $0.06 \mathrm{~L} \mathrm{~min}^{-1}$, respectively, and with a time resolution of $1 \mathrm{~s}$ for the PCASP and 5 and $1 \mathrm{~s}$ for the CPC during TRAQA and SAFMED, respectively.

The PCASP was factory calibrated with monodisperse polystyrene sphere latex (PSL) whose complex refractive index at the instrument operating wavelengths $(632.8 \mathrm{~nm})$ is $1.59-0 i$. The measured sphere-equivalent optical diameter has been converted to a sphere-equivalent geometrical diameter $\left(D_{\mathrm{g}}\right)$ by taking into account the complex refractive index of the sampled aerosol (Liu and Daum, 2000). Given that in the very large majority of cases the aerosol sampling during TRAQA and SAFMED was associated with the export of pollution plumes, only pollution aerosols have been considered for PCASP correction. Note that these data are not optimized for dust or marine aerosol observations. A large interval of values $(n \sim 1.50-1.72, k \sim 0.001-0.1$ for UV-visible wavelengths) are reported in the literature for the real and the imaginary parts of the refractive index for anthropogenic aerosols over Europe (e.g. Ebert et al., 2002, 2004; Müller et al., 2002; Mallet et al., 2003, 2011; Chazette et al., 2005; Raut and Chazette, 2008). For our calculations at $632.8 \mathrm{~nm}$ we fixed the imaginary part of the refractive index to 0.01 , thus representing a mean absorbing aerosol, and then we var- ied the real part between its minimum (1.50) and maximum (1.72) reported value. $D_{\mathrm{g}}$ is then set at the mean \pm one standard deviation of the values obtained for the different values of $n$. We assume in these calculations that the refractive index does not vary with height. After refractive index correction the $D_{\mathrm{g}}$ range for the PCASP becomes $0.10-4.47 \mu \mathrm{m}$, with an uncertainty between 1 and $25 \%$. The smallest and the largest size bins of the PCASP, for which the minimum and maximum edges respectively are not defined, have been excluded from the data sets, thus reducing the PCASP $D_{\mathrm{g}}$ range to $0.11-4.17 \mu \mathrm{m}$.

Once corrected for the refractive index, PCASP data have been combined with those from the CPC to calculate $\mathrm{d} N_{\text {Aitken }}, \mathrm{d} N_{\text {Acc }}$, and $\mathrm{d} N_{\text {Coarse }}$. Values for $\mathrm{d} N_{\text {Acc }}$ and $\mathrm{d} N_{\text {Coarse }}$ are obtained by integrating the PCASP number concentrations in the $0.1-1.0 \mu \mathrm{m}$ and $1.0-4.17 \mu \mathrm{m}$ ranges, while $\mathrm{d} N_{\text {Aitken }}$ is estimated as the difference between CPC concentration and the integral of PCASP data between 0.1 and $3.0 \mu \mathrm{m}$. The comparison between the PCASP and the GRIMM below $350 \mathrm{~m}$ altitude indicates that the former underestimates the aerosol concentration in the range of 0.4$1.0 \mu \mathrm{m}$ by about $50 \%$ (the accuracy of the GRIMM has been verified by optical closure study against simultaneous aircraft nephelometer measurements). This is estimated to induce a $\sim 20 \%$ underestimation of the $\mathrm{d} N_{\text {Acc }}$ calculated here. Conversely, the PCASP underestimation in the $0.4-1.0 \mu \mathrm{m}$ range has almost a negligible impact on $\mathrm{d} N_{\text {Aitken }}$.

CPC measurements, and so $\mathrm{d} N_{\text {Aitken }}$ data, were not available during SAFMED flights V49, V50, and part of V51.

\subsection{Trace gases}

Carbon monoxide $(\mathrm{CO})$ and ozone $\left(\mathrm{O}_{3}\right)$ mixing ratios were measured by the MOZART instrument described in detail by Nedelec et al. (2003). CO is a long-lived tracer for air masses influenced by combustion processes, whereas $\mathrm{O}_{3}$ in the troposphere is a photochemical product of the oxidation of $\mathrm{CO}$ and volatile organic compounds (VOCs) in the presence of nitrogen oxides $\left(\mathrm{NO}_{x}\right)$. $\mathrm{CO}$ and $\mathrm{O}_{3}$ are measured at a resolution of 30 and $4 \mathrm{~s}$, respectively. The nominal uncertainty is $\pm 5 \%$ for $\mathrm{CO}$ and $\pm 2 \%$ for $\mathrm{O}_{3}$ (Nedélec et al., 2003). However, a recent airborne intercomparison in May 2014 in the framework of the French ChemCalInt project and the TGOE (Traceability in Gas-phase Observations in EUFAR) European Joint Research Activity has suggested a greater uncertainty (up to $30 \%$ ) of CO measurements by MOZART on-board the ATR-42 (A. Borbon, personal communication, 2015). Trace gas analysis will focus mostly on the vertical distribution of the $\Delta \mathrm{O}_{3} / \Delta C \mathrm{C}$ ratio rather than absolute concentrations (see Sect. 5.3) and the uncertainty of CO should not affect data interpretation. 


\subsection{STP conversion}

In order to compare measurements obtained at different altitudes the data presented here are reported at standard temperature and pressure (STP) using $T=293.15 \mathrm{~K}$ and $p=$ $1013.25 \mathrm{hPa}$ (NIST, National Institute of Standards and Technology, values). Hence, the scattering coefficient is scaled to STP conditions and the particle concentrations are given as particles per standard $\mathrm{cm}^{-3}\left(\mathrm{scm}^{-3}\right)$. For a generic parameter $x$ measured at the temperature $T$ and pressure $p$, the conversion at STP is calculated with the formula

$x(\mathrm{STP})=x(T, p) \frac{T}{293.15} \frac{1013.25}{p}$.

$\mathrm{CO}$ and $\mathrm{O}_{3}$ do not need to be corrected for STP since the mixing ratio does not depend on temperature and pressure.

\subsection{Meteorological parameters}

The vertical profiles of the pressure $(p)$, the temperature $(T)$, the relative humidity $(\mathrm{RH})$ and the wind components towards the east and the north $(U, V)$ measured on board the ATR-42 have been used to analyse the atmospheric structure during flights. Starting from the measured parameters the potential temperature $(\theta)$ has been also calculated as $\theta=T\left(p_{0} / p\right)^{0.286}$ with $p_{0}=1013.2$ mbar. For each profile the height of the marine aerosol boundary layer (MABL) and planetary boundary layer (BL) has been estimated visually by looking at the vertical gradients of $T, \theta$, and RH. Meteorological parameters have been also used to calculate the vertical profiles of the gradient Richardson number $(R i)$ :

$R i=\frac{g}{\theta} \frac{\partial \theta}{\partial z} /\left(\left(\frac{\partial U}{\partial z}\right)^{2}+\left(\frac{\partial V}{\partial z}\right)^{2}\right)$.

In Eq. (2), $g$ is the gravitational acceleration and $z$ is the height. The $R i$ number is the ratio between the buoyancy force and the wind shear and it is used to indicate dynamic stability and the formation of clear air turbulence. Turbulence can develop when $R i$ is below the critical threshold $R i_{\text {crit }}=0.25$, while it is inhibited for $R i>1$ (e.g. Wallace and Hobbs, 2006). In this study the profiles of $R i$ are used to provide indications of favourable/unfavourable conditions for the development of turbulence within the atmosphere.

\subsection{Tracking the air mass back-trajectories}

The Lagrangian trajectory model FLEXTRA (FLEXible TRAjectories, Stohl et al., 1995) has been used in selected cases to track the origin of sampled air masses. Fiveday three-dimensional back-trajectories have been calculated using the ECMWF (European Centre for Medium-Range Weather Forecasts) operational analysis with a $0.5^{\circ}$ by $0.5^{\circ}$ horizontal resolution and up to 30 vertical model levels below $4000 \mathrm{~m}$. The model specific humidity and potential vorticity is also interpolated along the trajectory path.

\section{Meteorological conditions, aerosol load, and pollution export regimes}

In order to characterise the general aerosol conditions encountered over the western Mediterranean basin during the TRAQA and the SAFMED campaigns, we have plotted the time series of the aerosol optical depth $(\tau, \pm 0.02)$ at $440 \mathrm{~nm}$ and the 440-870 nm Ångström exponent $(\alpha)$ measured with a Cimel sunphotometer (Holben et al., 1998) at the three AERONET stations of Barcelona, Frioul, and Ersa, located along the coast around the western basin (see Fig. 1). Level 1.5 cloud-screened data are used in this study. Data are shown in Fig. 2 and correspond to the period of the campaign of measurements plus 10 days before and after. Table 1 reports the date, location, and main meteorological and export conditions encountered during TRAQA and SAFMED flights.

Over the analysed AERONET sites the aerosol optical depth was below 0.2 before the beginning of the TRAQA campaign and increased, especially at Barcelona and Ersa, to $\sim 0.3-0.5$ (with $1<\alpha<2$ ) in the periods 23-26 June and 313 July 2012. Isolated peaks of $\tau$ were measured corresponding to two Saharan dust intrusion events which occurred on 17-23 June $(\tau \sim 0.6)$ and 29 June $2012(\tau \sim 1.4)$. Different wind regimes occurred during TRAQA and favoured the continental outflow from different regions located around the basin. Two examples of wind maps derived from WRFChem model (Grell et al., 2005) at 925 mbar are shown in Fig. 3 for 26 June and 3 July 2012. Main observed meteorological/export conditions can be summarised as follows: (i) on 26-27 June north/north-westerly winds blew across northern Italy directing an air mass outflow towards the Gulf of Genoa (measurements on flights V19-V21); (ii) on the same days a strong mistral/tramontane episode (i.e. strong northerly winds developing along the Rhône and Aude valleys which bring a northerly/north-westerly flow over the western Mediterranean, see Fig. 3a) favoured the dispersion of pollutants towards the central part of the western basin. Measurements during the event were performed during flight V20; (iii) on 3-4 July the wind regime was dominated by westerly/south-westerly winds mostly blowing at the surface across the Iberian Peninsula and south-western France (see Fig. 3b). This condition allowed measuring the export of pollution from the Spanish coast, in particular close to the area of Barcelona (flights V24-V26, see Fig. 1). Additionally, flight V31 sounded the atmospheric structure close to the Spanish coast reaching the urban area south of Valencia. The flight was performed 1 week later (10 July) under similar meteorological conditions characterized by south-westerly winds favouring the export from the Iberian Peninsula towards the basin; (iv) mistral episodes occurred on 6-7 and 11 July 2012. In those cases the mistral wind combined with a persistent westerly flow, leading to pollution export towards the central and central-eastern part of the western basin, as measured during flights V27, V28, V30, V32; (v) finally, Sa- 

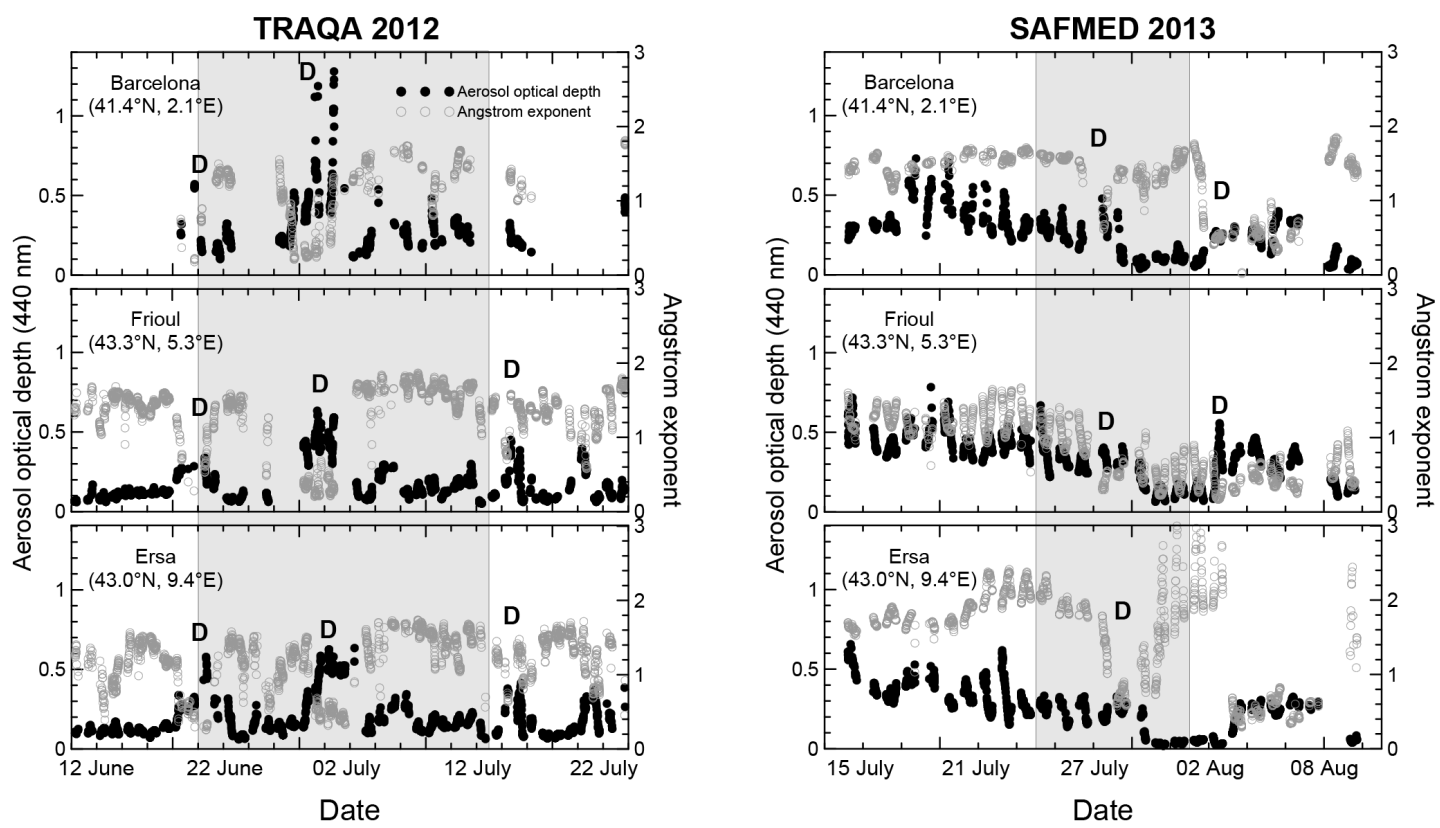

Figure 2. Aerosol optical depth at $440 \mathrm{~nm}(\tau)$ and Ångström exponent $(\alpha)$ measured at the Barcelona, Frioul, and Ersa AERONET stations during the TRAQA 2012 (left panels) and the SAFMED 2013 (right panels) campaigns. The time period for the different plots is \pm 10 days around the beginning/end of the two campaigns (data for the Barcelona station are not available over the entire 2012 period). The label D indicates the days affected by Saharan dust.

haran dust aerosols were sampled during flights V16 and V20 (episode of 17-23 June) and flights V22 and V23 (episode of 29 June).

During SAFMED the meteorological conditions were more stable and two distinct phases were observed: (i) a stable anticyclone affected the whole western Mediterranean area in the first half up until the 26th of July, thus possibly favouring a more pronounced accumulation of photochemical pollution in this part of the basin. Relatively high values of both $\tau(\sim 0.2-0.8)$ and $\alpha(\sim 1-2.5)$ were measured at the three sites of Barcelona, Frioul, and Ersa in this period; (ii) a cyclonic system moving from the Atlantic region towards Europe then affected the western basin on 28-29 July 2013. Very clean conditions $(\tau<0.1-0.2)$ were measured afterwards over the entire region until the end of the SAFMED campaign. Winds were mostly westerly/south-westerly in the first period of the campaign (24-29 July 2013, flights V46, V47, V48, V49, V50), which means that the sampled air flow came mostly from the sea. Then, from 30 July to $1 \mathrm{Au}-$ gust 2013 a north-easterly flow affected the SAFMED investigated area, thus promoting the export of pollution from northern Italy towards the Gulf of Genoa (flights V51, V52). A strong mistral event (29 July-1 August) and two Saharan dust outbreaks (27-28 July and 1 August) affected the western basin though not the vertical profile observations during SAFMED.

In order to identify the distribution of observations during TRAQA and SAFMED as a function of the aerosol type, in
Fig. 4 we plotted the distribution of the measured scattering coefficient $\sigma_{\mathrm{s}}$ at 450,550 , and $700 \mathrm{~nm}$ as a function of the calculated scattering Ångström exponent $\alpha_{\mathrm{s}}$ for all vertical profiles. The plot shows similar scattering intensity between cases dominated by coarse particles $\left(\alpha_{\mathrm{s}}<0.5-1.0\right)$, such as desert dust, and those dominated by fine particles $\left(\alpha_{\mathrm{S}}>1.0\right.$ $1.5)$, such as pollution aerosols. For both dust and pollution, $\sigma_{\mathrm{s}}$ peaks at about $100-120 \mathrm{Mm}^{-1}$. The frequency of occurrence of $\alpha_{\mathrm{s}}$ shows that pollution plumes represent the large majority of the cases observed, with more than $70 \%$ of measurements with $\alpha_{\mathrm{s}}>1.0$.

\section{Results}

Figure 5 shows the box and whisker plots of the aerosol scattering coefficient $\sigma_{\mathrm{s}}$ at 450,550 , and $700 \mathrm{~nm}$, particle number concentration in the Aitken ( $\left(N_{\text {Aitken }}\right)$ and accumulation $\left(\mathrm{d} N_{\mathrm{Acc}}\right)$ diameter ranges, and $\mathrm{CO}$ and $\mathrm{O}_{3}$ measured in the boundary layer (BL) and in the free troposphere (FT) within pollution plumes for all the different vertical soundings analysed in this study. This plot summaries the range of values observed during TRAQA and SAFMED. On average, the scattering coefficient and $\mathrm{CO}$ are larger in the BL compared to the FT, whilst similar ranges of values are measured in the two regions for $\mathrm{d} N_{\text {Aitken }}, \mathrm{d} N_{\mathrm{Acc}}$, and $\mathrm{O}_{3}$. Even within the single BL and FT the different parameters show a large variability that will be explored in the following paragraphs. 
a) 26 June 2012 12UT, $925 \mathrm{hPa}$

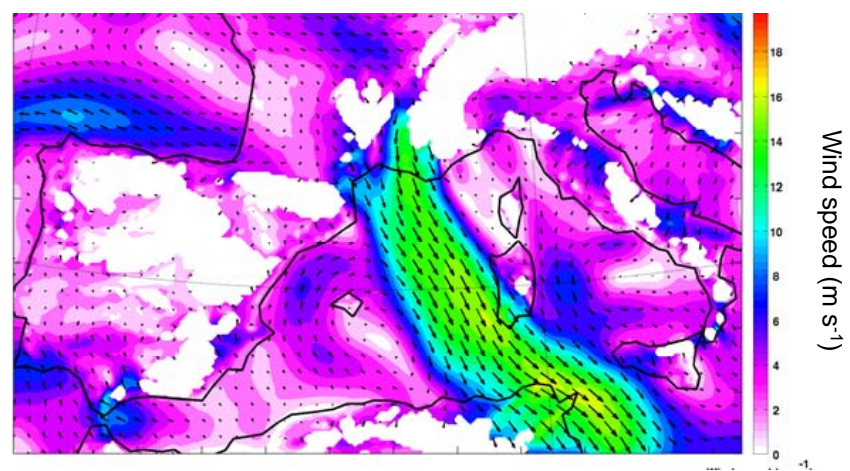

\section{b) 03 July $201212 \mathrm{UT}, 925 \mathrm{hPa}$}

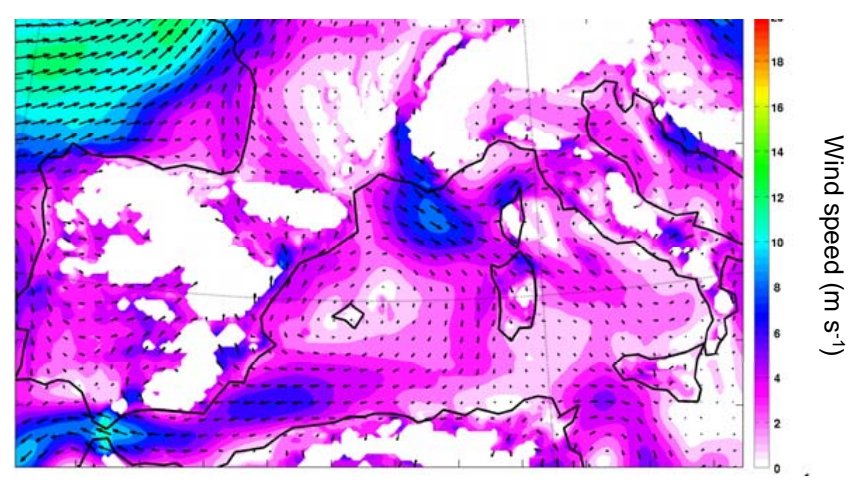

Figure 3. Example of wind maps at 925 mbar for 26 June and 3 July 2012. The maps are obtained from the WRF-Chem model (Weather Research and Forecasting - Chemistry) at $10 \mathrm{~km}$ horizontal resolution.

\subsection{Vertical profiles of aerosol concentration and scattering coefficient}

Figure 6 shows the vertical profiles of $\sigma_{\mathrm{s}}, \mathrm{d} N_{\mathrm{Acc}}$, and $\mathrm{d} N_{\text {Coarse }}$ during TRAQA and SAFMED flights. The date, time and coordinates of each profile, as well as the heights of the top of the marine and planetary boundary layer (MABL and BL) estimated from meteorological data, are also indicated in the plot.

For the different vertical soundings the particle concentrations $\mathrm{d} N_{\mathrm{Acc}}$ and $\mathrm{d} N_{\text {Coarse }}$ vary in the range of $\sim 30$ $3200 \mathrm{scm}^{-3}$ and $\sim 0.05-40 \mathrm{scm}^{-3}$, respectively, for plumes with $\sigma_{\mathrm{s}}$ between 10 and $120 \mathrm{Mm}^{-1}$. The structure in the scattering profile is generally mirrored in $\mathrm{d} N_{\text {Acc }}$ profile, and this also reflects the pronounced spectral variability (i.e. decrease for increasing wavelength) of the scattering coefficient, typical of pollution/anthropogenic particles. $\mathrm{d} N$ Coarse also contributes to the scattering signal in some cases especially at high altitudes (see V16, V20, V21, V22, and V23 above $\sim 2000 \mathrm{~m}$ ), and this reflects the low spectral variability of the scattering coefficient. These observations are associated with the dust intrusion episodes which occurred in the west- ern Mediterranean basin during TRAQA, which will not be analysed in detail here. Aerosol layers affected by dust have been labelled with a "D" in Fig. 6.

Maxima of the scattering coefficient have been measured for TRAQA flights V21 and V23 $\left(\sim 120 \mathrm{Mm}^{-1}\right.$ for pollution in the BL and $\sim 100 \mathrm{Mm}^{-1}$ in the dust layer), whereas flights V46, V48, V49, during the first and more polluted phase of SAFMED, are the richest in $\mathrm{d} N_{\text {Acc }}\left(1500-3000 \mathrm{scm}^{-3}\right.$ over the whole column). Minima of $\sigma_{\mathrm{s}}$ and $\mathrm{d} N_{\mathrm{Acc}}$ are obtained for flight V51 at the beginning of the second SAFMED phase when clean conditions were observed in the western Mediterranean.

Pollution plumes observed in the different flights extend from the boundary layer to the free troposphere up to 3000$4000 \mathrm{~m}$ altitude. The vertical structure of the aerosol scattering coefficient/particle concentration is linked to the variability of the atmospheric thermodynamic structure and is generally characterized by a first layer confined in the MABL (<400 m, profiles V16, V20, V22, V25, V48, V51), followed by one or more layers within the BL. In the FT pollution particles occur both as single isolated plumes each about 500-1000 $\mathrm{m}$ thick (V21, V24, V25, V30, V46, V49), or as a more uniform layer extending from the top of the BL up to 2500-4000 $\mathrm{m}$ altitude (V26, V27, V28, V32, V48). The highest values of both the scattering coefficient and $\mathrm{d} N_{\text {Acc }}$ for pollution are found within the MABL or BL in most cases, while a local minimum of $\sigma_{\mathrm{s}}$ and $\mathrm{d} N_{\mathrm{Acc}}$ is generally identified at the top of the BL. The scattering coefficient and the particle concentration measured in the FT are comparable with the values observed in the BL, and in a few cases even larger (V25, V26, V30). Only in one case (profile V31) do $\sigma_{\mathrm{s}}$ and $\mathrm{d} N_{\mathrm{Acc}}$ decrease monotonically with height. The aerosol vertical distribution, both in the BL and in the FT, often presents a strongly stratified structure characterized by the presence of several thin sub-layers within one main identified aerosol plume, as it can be seen in particular in the $\mathrm{d} N_{\text {Acc }}$ profiles (V20, V21, V22, V25, V46, V49).

The particle concentration in the Aitken mode (0.004-

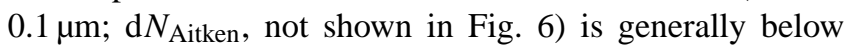
$5000-6000 \mathrm{scm}^{-3}$ at all altitudes up to $4000 \mathrm{~m}$ within pollution plumes. $\mathrm{d} N_{\text {Aitken }}$ is correlated with $\mathrm{d} N_{\text {Acc }}$ in most of the observed cases, which indicates the common source of particles in these two size ranges. A few layers exceeding $\sim 10000-15000 \mathrm{scm}^{-3}$ were observed occasionally both in the BL and in the FT. These will be discussed in more detail in Sect. 5.4.

The $\mathrm{d} N_{\text {Acc }}$ and $\mathrm{d} N_{\text {Aitken }}$ measurements within the BL and in the FT over the sea are comparable with the values measured close to the surface at continental sites under pollution conditions (see Table 2) (Petzold et al., 2002; Mallet et al., 2003, 2005; Wiegner et al., 2006; Junkermann, 2009; Hamburger et al., 2012; Highwood et al., 2012). This suggests that the export towards the basin favours the redistribution of the pollution plumes along the vertical. Because of mixing, measured concentrations within the BL can be as high as those 

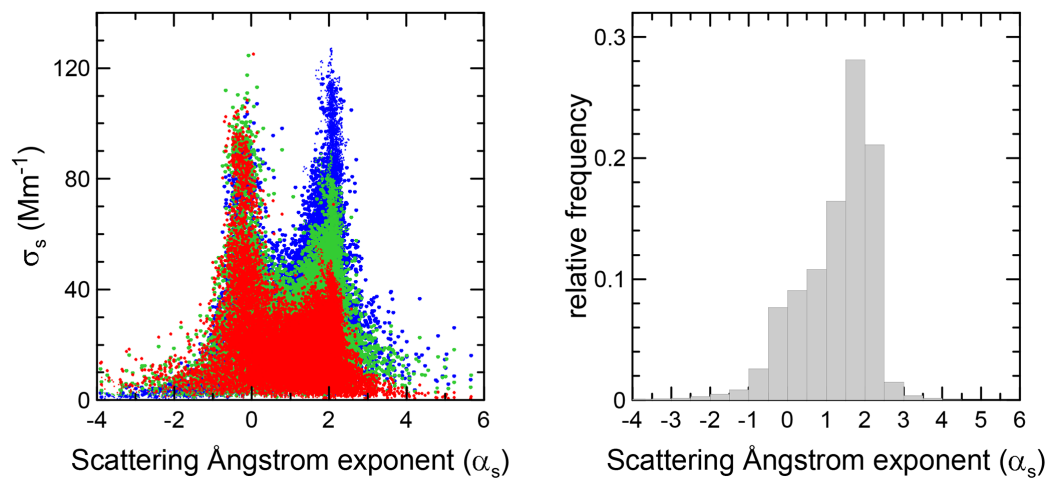

Figure 4. Left: scattering coefficient $\left(\sigma_{\mathrm{s}}\right)$ at 450, 550, and $700 \mathrm{~nm}$ versus the scattering Ångström exponent $\left(\alpha_{\mathrm{S}}\right)$. Cases with extremely negative $(<-2)$ and positive $(>4)$ values of $\alpha_{\mathrm{S}}$ are always related with very low scattering coefficients, and are likely due to instrumental noise under low scattering conditions. Right: frequency of occurrence of $\alpha_{\mathrm{S}}$ obtained considering vertical profiles data from all TRAQA and SAFMED flights.
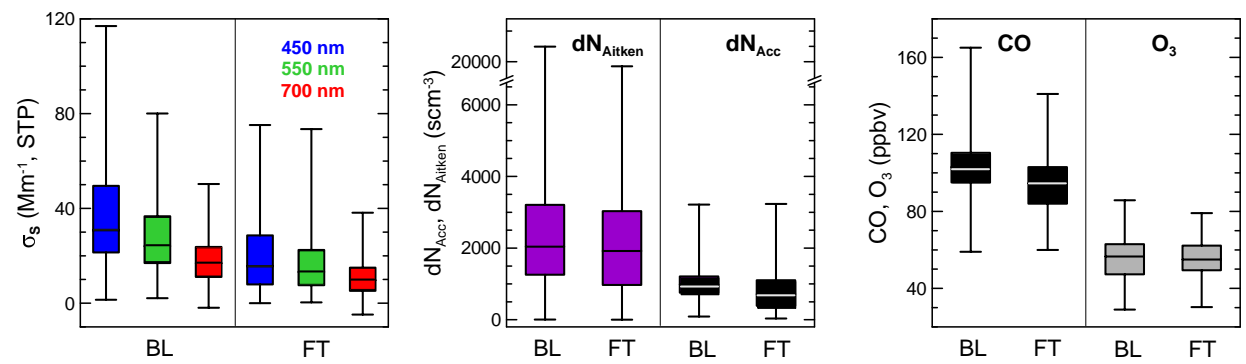

Figure 5. Box and whisker plot of the aerosol scattering coefficient $\left(\sigma_{\mathrm{S}}\right)$ at 450, 550, and $700 \mathrm{~nm}$, particle concentration in the Aitken $\left(\mathrm{d} N_{\text {Aitken }}\right)$ and accumulation $\left(\mathrm{d} N_{\mathrm{Acc}}\right)$ modes, and $\mathrm{CO}$ and $\mathrm{O}_{3}$ measured within pollution plumes in the boundary layer $(\mathrm{BL})$ and in the free troposphere (FT).

observed close to the surface over the continents. Values of $\mathrm{d} N$ as high as in the BL are observed in the FT because of transport in specific conditions, as discussed below.

The observations of aerosol profiles obtained during TRAQA and SAFMED are representative of the complex transport regimes which characterises the export towards the western basin and that is mostly determined by the interaction between regional meteorology and local dynamics (e.g. Gangoiti et al., 2001). A first example is associated with the measurements in the area of Barcelona. As discussed in Pérez et al. (2004) the presence of mountains up to $\sim 500$ $3000 \mathrm{~m}$ altitude a few kilometres inland favours, during summertime, the recirculation of pollutants along the coast of Spain. In these cases, the aerosols emitted at the surface in coastal areas are transported inland and uplifted by sea breezes and mountain winds, and then the plumes are reinjected at different altitudes and distances from the coast. During the TRAQA flights V24, V25, and V26, under the influence of pollution outflow from the Barcelona area, we detected the presence of aerosol layers with elevated concentrations ( $\left.\mathrm{d} N_{\mathrm{Acc}} \sim 2000-3000 \mathrm{scm}^{-3}\right)$ up to $3500 \mathrm{~m}$ altitude at a distance of $\sim 30$ to $250 \mathrm{~km}$ from the coast of Spain. Another example of complex dynamics linked to coastal orography is that associated with the export from northern Italy and the Po Valley towards the Gulf of Genoa. The presence of the Apennine Mountains close to the Ligurian coast (max elevation $\sim 1500-2000 \mathrm{~m}$ ) causes the uplift of continental air masses so determining the injection of aerosol plumes at different altitudes both inside and outside the BL. Examples are given by flights V19, V21 and V52 for which pollution aerosols from northern Italy are measured up to $\sim 2000-3000 \mathrm{~m}$ altitude throughout the Gulf of Genoa. Finally, another meteorological condition which largely influences the aerosol export and distribution over the western Mediterranean is the mistral/tramontane wind regime. Under the influence of the mistral flow, atmospheric aerosols can be dispersed as far as hundreds of kilometres over the open sea, as discussed by Salameh et al. (2007). Examples are given in profiles V20 and V28, performed at more than $100 \mathrm{~km}$ from the French coast, for which pollution layers associated with a mistral flow are measured up to 2000-3000 m altitude.

\subsection{Trace gases vertical profiles}

Figure 7 shows $\mathrm{O}_{3}$ versus $\mathrm{CO}$ for all TRAQA and SAFMED flights, while examples of $\mathrm{CO}$ and $\mathrm{O}_{3}$ profiles, representative of different conditions, are reported in Figs. 8 and 10. 
TRAQA 2012
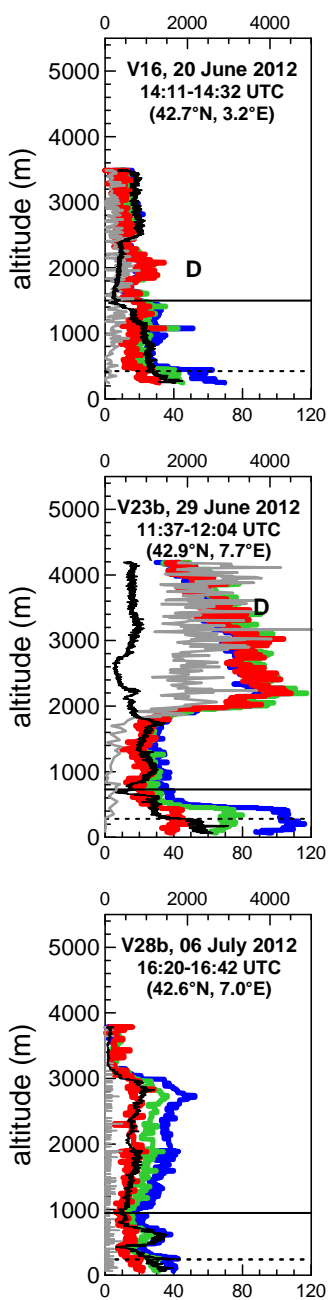

Particle number concentration, $\mathrm{dN}_{\mathrm{Acc}}\left(\mathrm{scm}^{-3}\right)$ and $\mathrm{dN}_{\text {coarse }}\left(10^{-2} \mathrm{scm}^{-3}\right)$
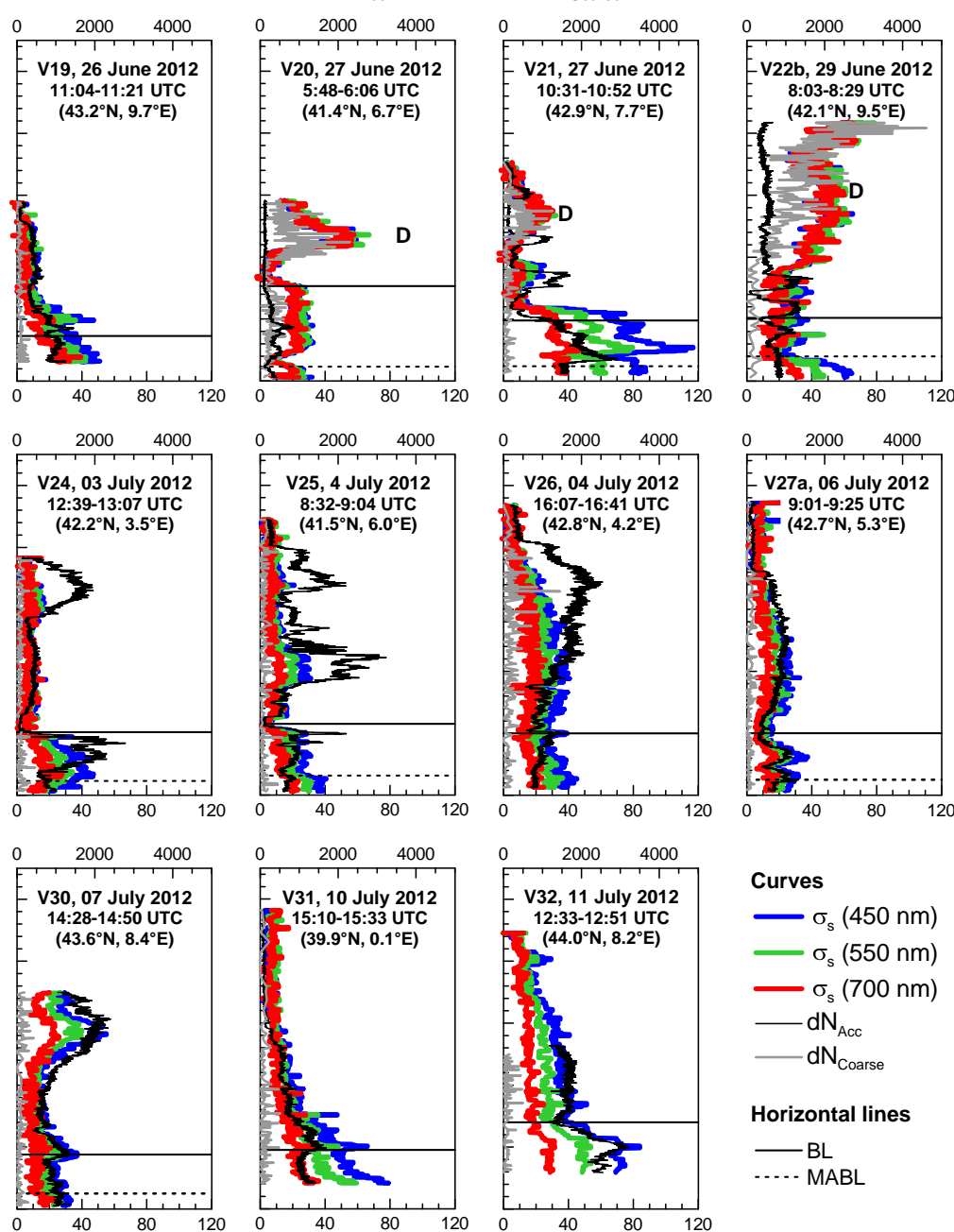

Horizontal lines

BL

.... MABL

\section{SAFMED 2013}
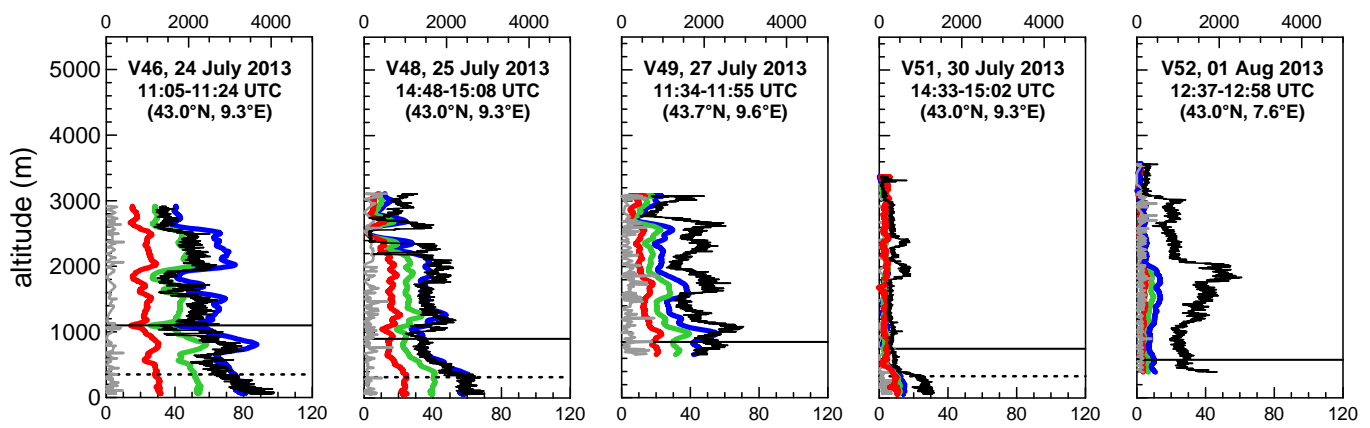

Particle scattering coefficient, $\sigma_{\mathrm{s}}\left(\mathrm{Mm}^{-1}, \mathrm{STP}\right)$

Figure 6. Vertical profiles of the spectral scattering coefficient $\sigma_{\mathrm{S}}$ at 450,550 , and $700 \mathrm{~nm}$ and particle number concentration in the $0.1-$ $1.0 \mu \mathrm{m}\left(\mathrm{d} N_{\mathrm{Acc}}\right)$ and 1.0-4.0 $\mu \mathrm{m}\left(\mathrm{d} N_{\text {Coarse }}^{*}\right)$ diameter ranges observed during TRAQA and SAFMED. Data are reported at STP (standard temperature and pressure, $T=293.15 \mathrm{~K}$ and $P=1013.25 \mathrm{hPa}$ ). The heights of the top of the marine aerosol boundary layer (MABL) and planetary boundary layer (BL) estimated from the meteorological profiles are also indicated in the plots. The label D is used to identify the aerosol layers affected by Saharan dust. For certain flights (V22, V23, V27, and V28) two vertical soundings were performed; the letters "a" and "b" after the flight number in this plot distinguish between data taken from the first and the second sounding, respectively. (* data for $\mathrm{d} N_{\text {Coarse }}$ are multiplied by 100 in the plot). 
Table 2. Comparison of the number concentrations $\mathrm{d} N_{\text {Aitken }}(0.004-0.1 \mu \mathrm{m})$ and $\mathrm{d} N_{\text {Acc }}(0.1-1.0 \mu \mathrm{m})$ observed during the TRAQA/SAFMED field campaigns with those reported in literature for continental Europe. All literature data refer to airborne measurements.

\begin{tabular}{llll}
\hline Atmospheric layer & Parameter & TRAQA/SAFMED & Literature values for continental Europe \\
\hline \multirow{2}{*}{ Free troposphere $(\mathrm{FT})$} & $\mathrm{d} N_{\text {Aitken }}\left(\mathrm{scm}^{-3}\right)$ & $0-19250$ & $812-9149^{\mathrm{b}} ; 0-980^{\mathrm{e}}$ \\
& $\mathrm{d} N_{\text {Acc }}\left(\mathrm{scm}^{-3}\right)$ & $34-3233$ & $20-80^{\mathrm{a}} ; 25-85^{\mathrm{e}} ; 0-500^{\mathrm{f}}$ \\
\hline \multirow{2}{*}{ Boundary layer $(\mathrm{BL})$} & $\mathrm{d} N_{\text {Aitken }}\left(\mathrm{scm}^{-3}\right)$ & $4-22471$ & $1037-31370^{\mathrm{b}} ; 1000-20000^{\mathrm{c}} ; 0-30000^{\mathrm{d}} ; 0-19000^{\mathrm{e}}$ \\
& $\mathrm{d} N_{\text {Acc }}\left(\mathrm{scm}^{-3}\right)$ & $90-3215$ & $70-560^{\mathrm{a}} ; 10-50^{\mathrm{c}} ; 400-1200^{\mathrm{e}} ; 0-2000^{\mathrm{f}}$ \\
\hline
\end{tabular}

${ }^{\text {a }}$ Petzold et al. (2002), central Europe, July-August 1998; size range $\mathrm{d} N_{\text {Acc }}(>0.15 \mu \mathrm{m}) .{ }^{\mathrm{b}}$ Mallet et al. (2005), south-eastern France, June 2001; size range $\mathrm{d} N_{\text {Aitken }}(0.006-0.6 \mu \mathrm{m}) .{ }^{\mathrm{c}}$ Wiegner et al. (2006), Germany, May 2003; size range $\mathrm{d} N_{\text {Aitken }}(>0.01 \mu \mathrm{m}), \mathrm{d} N_{\text {Acc }}(>0.3 \mu \mathrm{m}) .{ }^{\mathrm{d}}$ Junkermann (2009), Po Valley, July-August 2002 and September-October 2003 ; size range $\mathrm{d} N_{\text {Aitken }}(>0.01 \mu \mathrm{m}) .{ }^{\mathrm{e}}$ Hamburger et al. (2012), central Europe, May 2008; size range $\mathrm{d} N_{\text {Aitken }}$ $(0.004-0.15 \mu \mathrm{m}), \mathrm{d} N_{\text {Acc }}(>0.15 \mu \mathrm{m}){ }^{\mathrm{f}}$ Highwood et al. (2012), central Europe, May 2008; size range $\mathrm{d} N_{\text {Aitken }}(0.004-0.15 \mu \mathrm{m}), \mathrm{d} N_{\text {Acc }}(>0.15 \mu \mathrm{m})$.

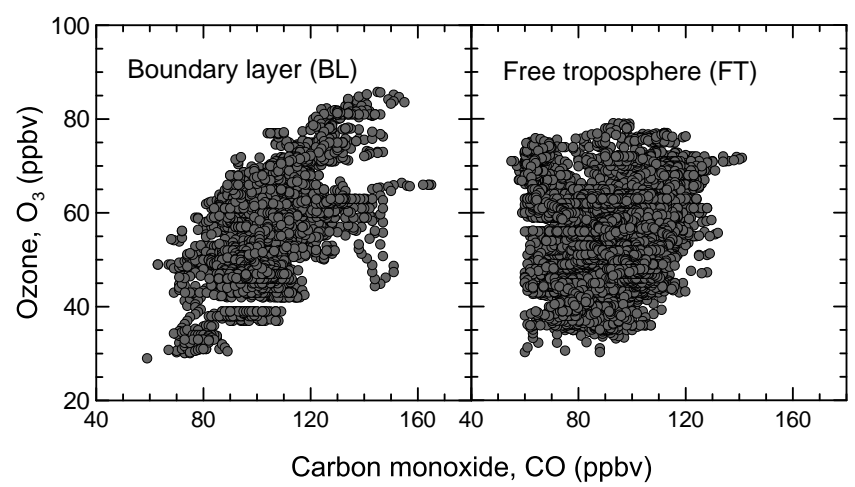

Figure 7. $\mathrm{O}_{3}$ versus $\mathrm{CO}$ in the boundary layer $(\mathrm{BL})$ and the free troposphere (FT) for all TRAQA and SAFMED vertical profiles (dust observations excluded).

$\mathrm{CO}$ and $\mathrm{O}_{3}$ vary in the range of $60-165$ and $30-85 \mathrm{ppbv}$, respectively. The 25th and 75th percentiles are 87 and $105 \mathrm{ppbv}$ for $\mathrm{CO}$ and 49 and $62 \mathrm{ppbv}$ for $\mathrm{O}_{3}$, representative of moderate pollution conditions (i.e. Parrish et al., 1998). By comparison, the values measured over land in central Italy during flight $\mathrm{V} 49$ are in the range of $80-180 \mathrm{ppbv}$ for carbon monoxide and 40-85 ppbv for ozone. $\mathrm{CO}$ and $\mathrm{O}_{3}$ are generally correlated (correlation coefficient $R^{2} \sim 0.5-0.8$ ) within measured pollution plumes, and also correlated with $\sigma_{\mathrm{s}}$ and $N_{\text {Acc }}$ both in the BL and in the FT, which indicates photochemically active plumes. $\mathrm{CO}$ is generally higher in the $\mathrm{BL}$, and shows absolute maxima in the lowest levels (V20, V21, V24, V28, V46), then decreasing in the FT. Ozone presents a more complicated vertical structure due to the different photochemical and dynamical processes which control its formation and distribution. At first, local peaks of $\mathrm{O}_{3}$ correlated with $\mathrm{CO}$ are observed corresponding to pollution plumes both in the BL and in the FT. An absolute maximum of $\mathrm{O}_{3}$ is sometimes found near the top of the $\mathrm{BL}$ (V24, V25, V30) possibly due to aged air masses trapped in the boundary layer. Isolated peaks of $\mathrm{O}_{3}(\sim 75-80 \mathrm{ppbv})$ not correlated with aerosols and $\mathrm{CO}$ are also measured in a few cases above 3000-3500 $\mathrm{m}$ (V21, V25, V27, V28, V52). The analysis of back-trajectories indicates that these high-altitude ozone layers are associated with the descent of air masses travelling at about $7-8 \mathrm{~km}$, which thus may suggest a downward transport from the upper troposphere or the tropopause region due to a stratosphere-troposphere exchange (Ancellet and Ravetta, 2005). Finally, absolute minima of $\mathrm{O}_{3}(\sim 15-$ $30 \mathrm{ppbv}$ ) are measured within the dust layers during flights V20 and V21, maybe related to the dust/ozone heterogeneous reactions which lead to $\mathrm{O}_{3}$ destruction, as documented in several studies (Bonasoni et al., 2004; Haywood et al., 2011).

\section{$5.3 \Delta \mathrm{O}_{3} / \Delta \mathrm{CO}$ and $\mathrm{d} N_{\mathrm{Aitken}} / \mathrm{d} N_{\mathrm{Acc}}$ ratios and variability of pollution plume composition}

Using the $\mathrm{O}_{3}, \mathrm{CO}, \mathrm{d} N_{\text {Aitken }}$ and $\mathrm{d} N_{\text {Acc }}$ measurements we have estimated

- the $\mathrm{O}_{3}-\mathrm{CO}$ enhancement ratio $\left(\Delta \mathrm{O}_{3} / \Delta \mathrm{CO}\right)$, i.e. the ratio of the ozone to carbon monoxide variations compared to their baseline values. The $\Delta \mathrm{O}_{3} / \Delta \mathrm{CO}$ enhancement ratio is frequently used to estimate the efficiency of $\mathrm{O}_{3}$ formation and its export (Parrish et al., 1993; Zhang et al., 2006). From our observations (Fig. 7) we have estimated a background value of $\sim 70 \mathrm{ppbv}$ in the $\mathrm{BL}$ and $60 \mathrm{ppbv}$ in the $\mathrm{FT}$ for $\mathrm{CO}$ and $\sim 30 \mathrm{ppbv}$ for $\mathrm{O}_{3}$ both in the BL and in the FT;

- the Aitken-to-accumulation number ratio $\left(\mathrm{d} N_{\text {Aitken }} / \mathrm{d} N_{\text {Acc }}\right)$, which defines the relative importance of particles in the Aitken and accumulation modes. $\mathrm{d} N_{\text {Aitken }}$ is generally associated with gas-toparticle conversion and nucleation events and is higher in fresh plumes, while it decreases with increasing plume lifetime due to coagulation or condensation of water-soluble chemical species on the particle surface (Kulmala et al., 2004).

The combination of $\Delta \mathrm{O}_{3} / \Delta \mathrm{CO}$ and $\mathrm{d} N_{\text {Aitken }} / \mathrm{d} N_{\text {Acc }}$ has been used to retrieve additional information on the atmospheric vertical structure, layering, and particle aging.

Within detected pollution plumes, $\Delta \mathrm{CO}$ and $\Delta \mathrm{O}_{3}$ reach up to $100-120 \mathrm{ppbv}$ and $45-55 \mathrm{ppbv}$, respectively, with a cor- 
responding $\Delta \mathrm{O}_{3} / \Delta \mathrm{CO}$ ratio which varies in the range of $\sim 0.10-2.0$ for all cases. The $\Delta \mathrm{O}_{3} / \Delta \mathrm{CO}$ ratio is highly noisy and this is due in part to the noise in the CO data, and in part also possibly associated with the slight mismatch between $\mathrm{CO}$ and $\mathrm{O}_{3}$ caused by their different time resolution ( $30 \mathrm{~s}$ for $\mathrm{CO}$ and $4 \mathrm{~s}$ for $\mathrm{O}_{3}$ ). The values of $\Delta \mathrm{O}_{3} / \Delta \mathrm{CO}$ obtained in this study are comparable with the range of observations available in the literature for fresh and moderately aged pollution plumes in the BL and in the lower FT $(\sim 0.2-1.0)$ (Chin et al., 1994; Parrish et al., 1998; Zhang et al., 2006; Cristofanelli et al., 2013). $\mathrm{d} N_{\text {Aitken }} / \mathrm{d} N_{\text {Acc }}$ is between about 1 and 20 in most pollution cases, which indicates the presence of both fresh layers rich in Aitken particles and aged plumes poor in Aitken particles. Extremely high values of $\mathrm{d} N_{\text {Aitken }} / \mathrm{d} N_{\text {Acc }}$ $(\sim 50-200)$ are measured in a few cases in layers with very low $\mathrm{d} N_{\text {Acc }}$ concentrations.

The large variability in $\Delta \mathrm{O}_{3} / \Delta \mathrm{CO}$ and $\mathrm{d} N_{\text {Aitken }} / \mathrm{d} N_{\mathrm{Acc}}$ indicates a strong heterogeneity, in terms of composition and lifetime for the different observed plumes. This heterogeneity reflects the complexity in terms of sources, production processes, and transport mechanisms, which characterises the western basin. In order to illustrate this point, we have selected three examples representative of different conditions observed in different areas of the basin: (i) V19, performed in the Gulf of Genoa corresponding to continental outflow events from northern Italy/Po Valley; (ii) V20, performed in southern France during a mistral event; (iii) V24, which measured the export of pollution from the area of Barcelona. The vertical profiles of the spectral scattering coefficient $\sigma_{\mathrm{s}}$, temperature $T$, relative humidity $\mathrm{RH}, \mathrm{d} N_{\text {Acc }}, \mathrm{d} N_{\text {Aitken }}, \mathrm{CO}, \mathrm{O}_{3}$, $\Delta \mathrm{O}_{3} / \Delta \mathrm{CO}, \mathrm{d} N_{\text {Aitken }} / \mathrm{d} N_{\text {Acc }}$ and wind are reported in Fig. 8 for these cases.

1. V19: export from northern Italy/Po Valley. The profile shown for flight V19 (Fig. 8a) is characterized by the presence of three different aerosol structures: the first one below $800 \mathrm{~m}$, characterized by a lower $\mathrm{d} N_{\text {Aitken }} / \mathrm{d} N_{\text {Acc }}(\sim 1-5)$ and relatively high $\Delta \mathrm{O}_{3} / \Delta \mathrm{CO}$ $(\sim 0.4-1.5)$, possibly associated with moderately aged pollution; the second one between 800 and $2600 \mathrm{~m}$, richer in fine particles $\left(\mathrm{d} N_{\text {Aitken }} / \mathrm{d} N_{\text {Acc }} \sim 5-15\right)$, so possibly linked to fresher emissions; and the third one above $2600 \mathrm{~m}$, where the $\mathrm{d} N_{\text {Aitken }} / \mathrm{d} N_{\text {Acc }}$ ratio rises rapidly, as will be further discussed in Sect. 5.4. The export of fresh pollution at $800-2600 \mathrm{~m}$ from northern Italy as observed in V19 may be related to the peculiar orography of this region and the uplift of continental air masses. This is confirmed by the analysis of the backtrajectories (Fig. 9) which indicates that the air masses arriving at 1000 and $2000 \mathrm{~m}$ passed over the western Po Valley at an altitude of about 400-1200 $\mathrm{m}$ and were then uplifted near the Ligurian coast to enter the basin above the BL. Junkermann (2009) measured high levels of fine particles up to about $2000 \mathrm{~m}$ in the western Po Valley, which means that the altitudes of $400-1200 \mathrm{~m}$ reached by our investigated air masses could have been sufficient for them to collect fresh emitted particles along their path. Conversely, below $800 \mathrm{~m}$ the air mass trajectory shows a longer subsidence over the sea surface in the troposphere which has possibly favoured the advection of more aged plumes, or the mixing with sea salts, thus inducing the decrease of the $\mathrm{d} N_{\text {Aitken }} / \mathrm{d} N_{\text {Acc }}$ ratio. It should be noted that the aerosol layer in the FT also shows relatively higher values of the $\Delta \mathrm{O}_{3} / \Delta \mathrm{CO}$ ratio $(\sim 0.6-1.0)$ compared to the more aged plume in the BL. The enhanced amount of $\mathrm{O}_{3}$ in this air mass can be linked to a high concentration of volatile precursors which may have favoured the build-up of ozone during the plume evolution. In a recent work, Kaiser et al. (2015) suggest that in the Po Valley the high content of formaldehyde, also observed by Junkermann et al. (2009), may be responsible for the excess of $\mathrm{O}_{3}$ production. Fresh layers in the FT up to $\sim 2000-3000 \mathrm{~m}$ possibly associated with pollution export from northern Italy were also observed during flights V21 and V52 (not shown).

2. V20: export during a mistral/tramontane event. As shown in Fig. 8b, winds from the northwest are measured at all altitudes during flight V20. The aerosol profile in the BL is characterized in the first $\sim 400 \mathrm{~m}$ by the presence of a layer richer in $\mathrm{d} N_{\text {Aitken }}$ $\left(\mathrm{d} N_{\text {Aitken }} / \mathrm{d} N_{\text {Acc }}>20\right)$ and $\mathrm{CO}(100 \mathrm{ppbv}$ close to the surface; $\mathrm{CO}$ data not available between 150 and $650 \mathrm{~m}$ ) possibly linked to fresh pollution, followed by the alternation of several layers characterized by a variable $\mathrm{d} N_{\text {Aitken }}\left(1000-6000 \mathrm{scm}^{-3}\right)$ and lower CO $(\sim 70 \mathrm{ppbv})$. A local minimum of $\mathrm{d} N_{\text {Aitken }}$ and $\sigma_{\mathrm{s}}$ is found at $\sim 400 \mathrm{~m}$. For all these layers the $\mathrm{O}_{3}$ is very low ( $\sim 30-40 \mathrm{ppbv})$ and the $\Delta \mathrm{O}_{3} / \Delta \mathrm{CO}$ ratio is $<0.6-$ 0.8 . At higher altitudes, between 1400 and $2000 \mathrm{~m}$, we observe a layer enriched in $\mathrm{O}_{3}\left(\Delta \mathrm{O}_{3} / \Delta \mathrm{CO} \sim 1-2\right)$, corresponding to an almost aerosol-free region. This enriched ozone layer might be possibly associated with a downward transport from higher tropospheric layers (as also suggested by the back-trajectories (Fig. 9)) or with mixing together with ozone rich layers along the air mass trajectory. Larger particles, from long-range transport of Saharan dust at latitudes below $30^{\circ} \mathrm{N}$, are measured between 2000 and $3000 \mathrm{~m}$, with a minimum of $\mathrm{O}_{3}(\sim 15-20 \mathrm{ppbv})$ registered within the layer. Several other flights were performed during mistral/tramontane episodes (V27, V28, V30, V32) and show, similarly to V20, the presence of several layers both in the BL and the FT.

3. V24: export from the Barcelona area. Measurements during V24 may be taken as representative of local recirculation (Pérez et al., 2004). In the V24 profile in Fig. 8c we may recognize up to five different aerosol layers. A first layer at $<200 \mathrm{~m}$ within 

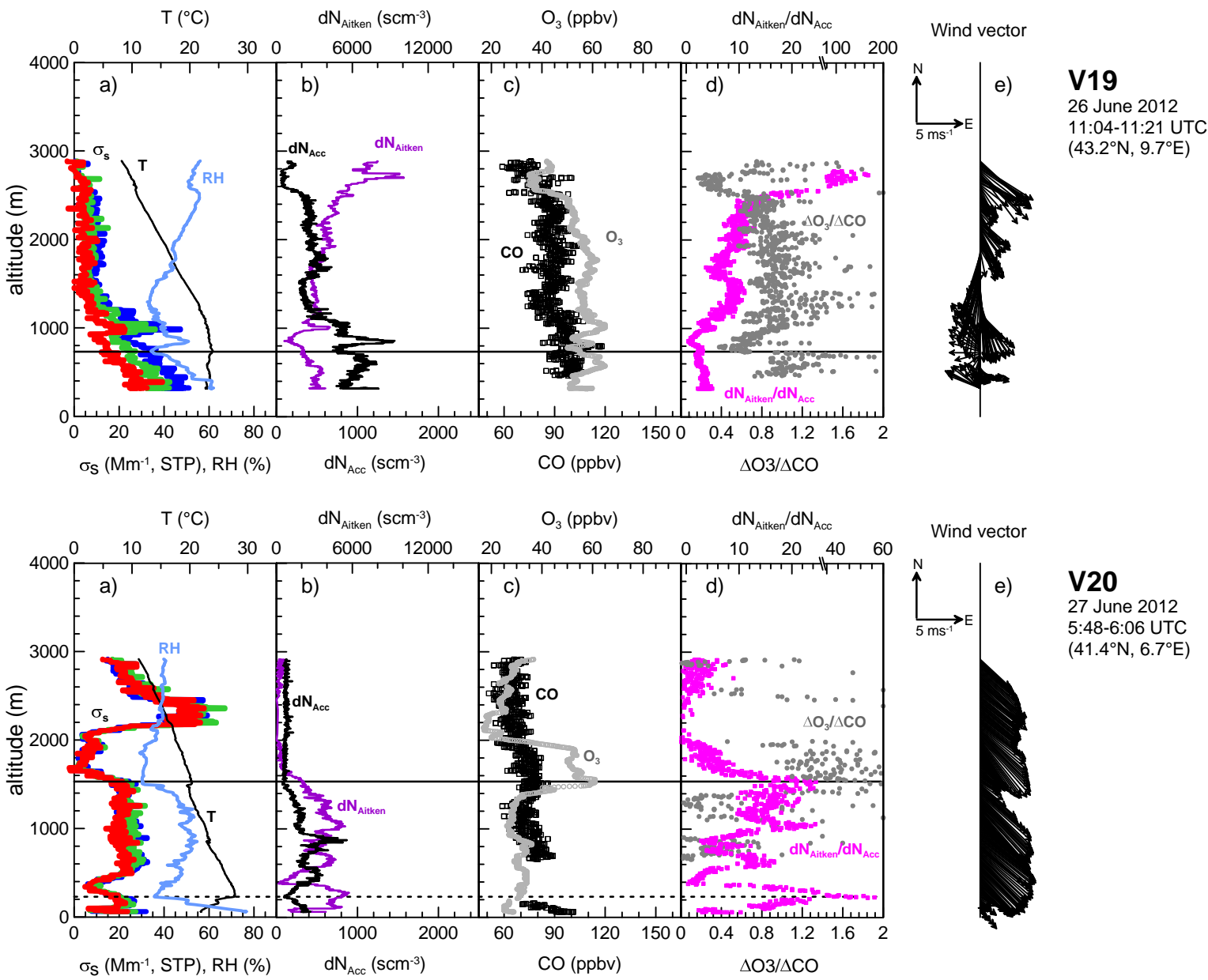

Wind vector
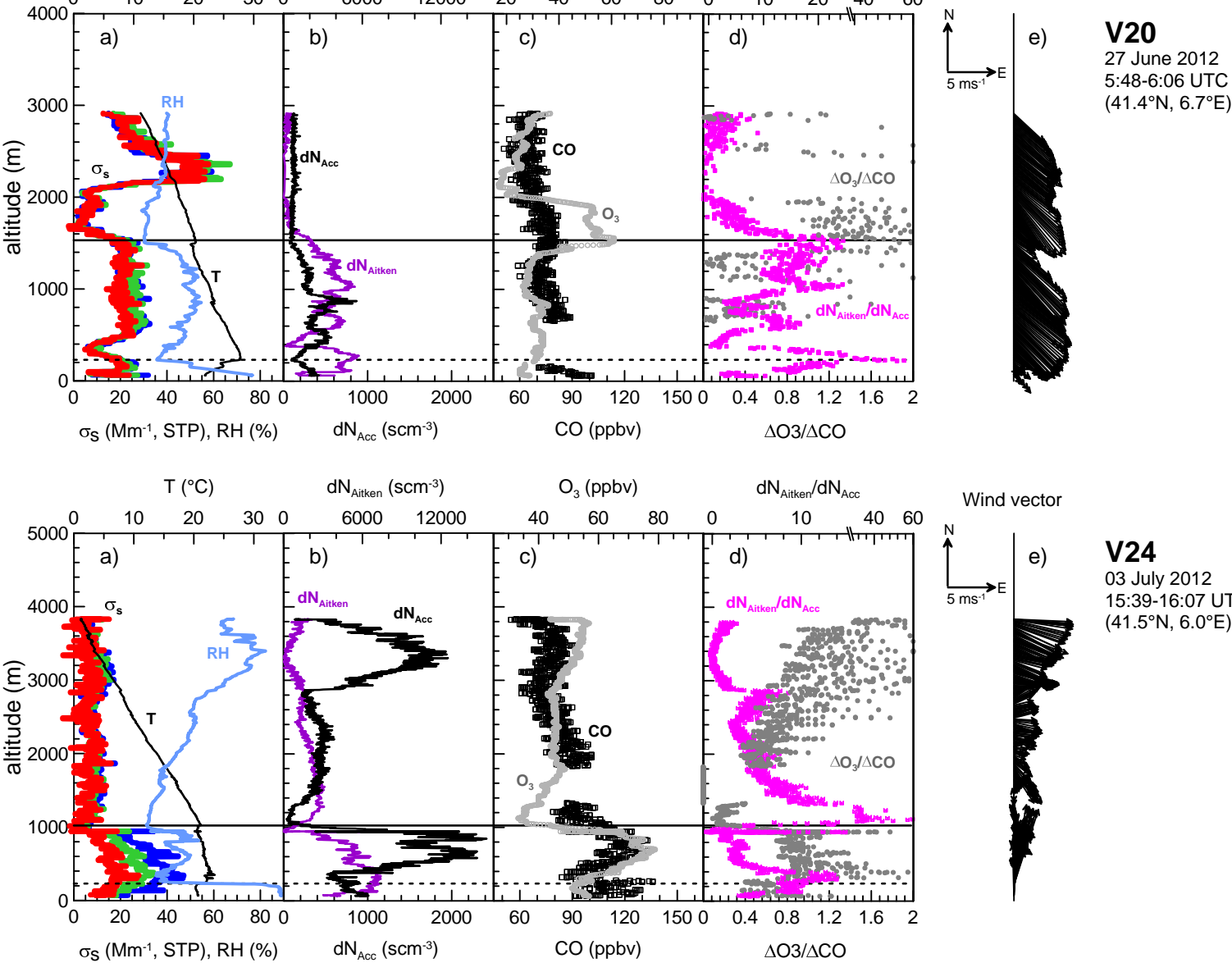

Wind vector

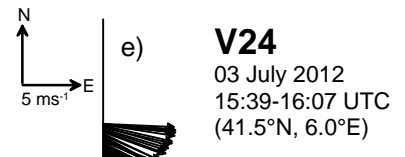

Figure 8. Aerosol and trace gases vertical profiles for flights V19 (export from northern Italy/Po Valley), V20 (mistral event), and V24 (export from the Barcelona area). The plots show the (a) spectral scattering coefficient $\sigma_{\mathrm{s}}$ at 450,550 , and $700 \mathrm{~nm}$ (blue, green, and red lines, respectively), temperature ( $T$, black line), and relative humidity (RH, light blue line); (b) particle number concentration in the $0.004-0.1 \mu \mathrm{m}$ ( $\mathrm{d} N_{\text {Aitken }}$, purple line) and 0.1-1.0 $\mu \mathrm{m}\left(\mathrm{d} N_{\mathrm{Acc}}\right.$, black line) diameter ranges; (c) $\mathrm{CO}$ (black dots) and $\mathrm{O}_{3}$ (grey dots) mixing ratios; (d) ozone enhancement factor $\Delta \mathrm{O}_{3} / \Delta \mathrm{CO}$ (grey dots) and Aitken-to-accumulation ratio $\mathrm{d} N_{\text {Aitken }} / \mathrm{d} N_{\text {Acc }}$ (pink dots); and (e) horizontal wind vector. The heights of the top of the MABL (dotted line) and BL (solid line) are also indicated. 

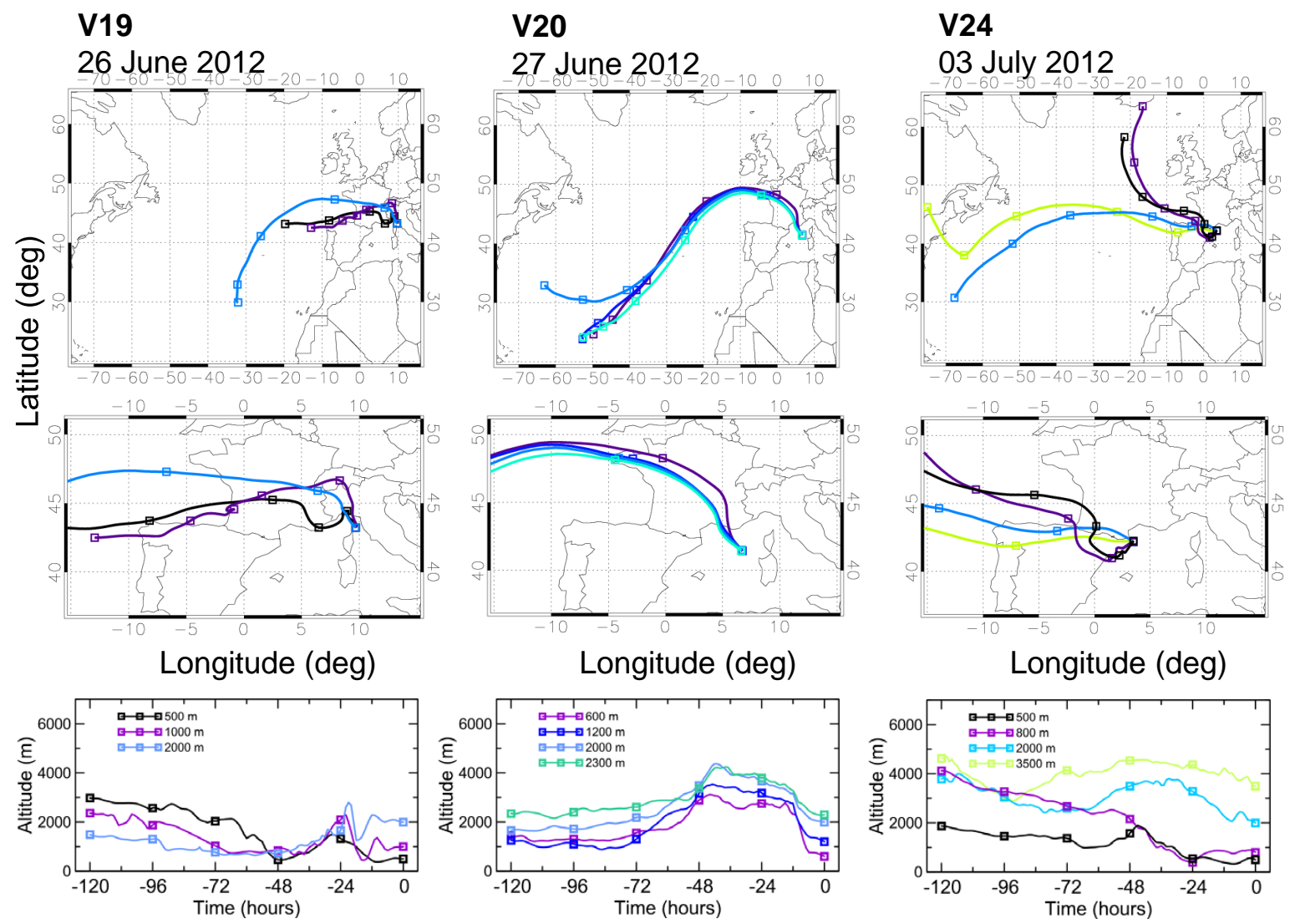

Figure 9. Five-day backward air mass trajectories for the V19, V20, and V24 flights calculated with the FLEXTRA model. The upper panel shows the trajectories over an extended latitude-longitude region, while the central panel focuses on the western Mediterranean area. The altitude of the air masses and its temporal evolution along the 5-day trajectories is reported in the lower panel of each plot.

the MABL, coming from the south-west and directly exported from the area of Barcelona. The layer is characterized by high CO (90-120 ppbv), and relatively low values of $\mathrm{d} N_{\text {Aitken }}\left(\sim 4000 \mathrm{scm}^{-3}\right)$ and $\mathrm{O}_{3}$ ( $\left.\sim 50 \mathrm{ppbv}\right)$, which possibly suggest the mixing of pollution with marine particles close to the sea surface. A second layer of fresher particles, always coming from the south-west, is observed above the MABL between 200 and $600 \mathrm{~m}\left(\mathrm{~d} N_{\text {Aitken }} \sim 6000\right.$ $8000 \mathrm{scm}^{-3}, \mathrm{O}_{3} \sim 70 \mathrm{ppb}$, with $\mathrm{d} N_{\text {Aitken }} / \mathrm{d} N_{\text {Acc }} \sim 5-15$, and $\left.\Delta \mathrm{O}_{3} / \Delta \mathrm{CO} \sim 0.8-1.5\right)$. A third, more aged, sublayer $\left(\mathrm{d} N_{\text {Aitken }} / \mathrm{d} N_{\text {Acc }} \sim 2-5, \Delta \mathrm{O}_{3} / \Delta \mathrm{CO} \sim 0.8-1.0\right)$ is observed within the BL between 600 and $1000 \mathrm{~m}$. The FT is characterized by the presence of moderately aged plumes from $\sim 1000$ to $2800 \mathrm{~m}\left(\mathrm{~d} N_{\text {Aitken }} / \mathrm{d} N_{\text {Acc }} \sim 2-\right.$ $\left.10, \Delta \mathrm{O}_{3} / \Delta \mathrm{CO} \sim 0.2-0.8\right)$, and a very aged plume at 2800-3800 m almost devoid in Aitken particles and richer in $\mathrm{O}_{3}\left(\mathrm{~d} N_{\text {Aitken }} / \mathrm{d} N_{\mathrm{Acc}}<1, \Delta \mathrm{O}_{3} / \Delta \mathrm{CO} \sim 0.6\right.$ 1.5). A marked local minimum is observed at the top of the $\mathrm{BL}$ for $\sigma_{\mathrm{s}}, \mathrm{d} N_{\mathrm{Acc}}, \mathrm{d} N_{\text {Aitken }}, \mathrm{CO}$, and $\mathrm{O}_{3}$, suggesting the presence of air masses with different origin between the BL and the FT. This is also confirmed by the analysis of the back-trajectories (Fig. 9), which indicates a low level air masses coming from the Spanish coast in the $\mathrm{BL}$, and air masses travelling at higher altitudes in the FT. In particular, the layer at $2800-3800 \mathrm{~m}$ is possibly associated with intercontinental transport from North America, as shown in the trajectory ending at $3500 \mathrm{~m}$. A similar structure characterized by the alternation of fresher and more aged plumes in the BL and FT is also observed in V25 for which aerosol layers are detected up to $4000 \mathrm{~m}$ altitude.

The detailed analysis of these three events evidences the complexity of the atmospheric structure over the western Mediterranean basin in relation to the different dynamical processes involved.

\subsection{Layers with enhanced Aitken-mode particle numbers}

Isolated layers with $\mathrm{d} N_{\text {Aitken }}$ values of $\sim 10000$ $15000 \mathrm{scm}^{-3}$ were observed occasionally both in the $\mathrm{BL}$ and in the FT. The vertical profiles of $\mathrm{d} N_{\text {Aitken }}$ for some selected cases are shown in Fig. 10.

For about half of the observed events the $\mathrm{d} N_{\text {Aitken }}$ layer appears related to a simultaneous increase in $\mathrm{d} N_{\mathrm{Acc}}, \mathrm{CO}$, 

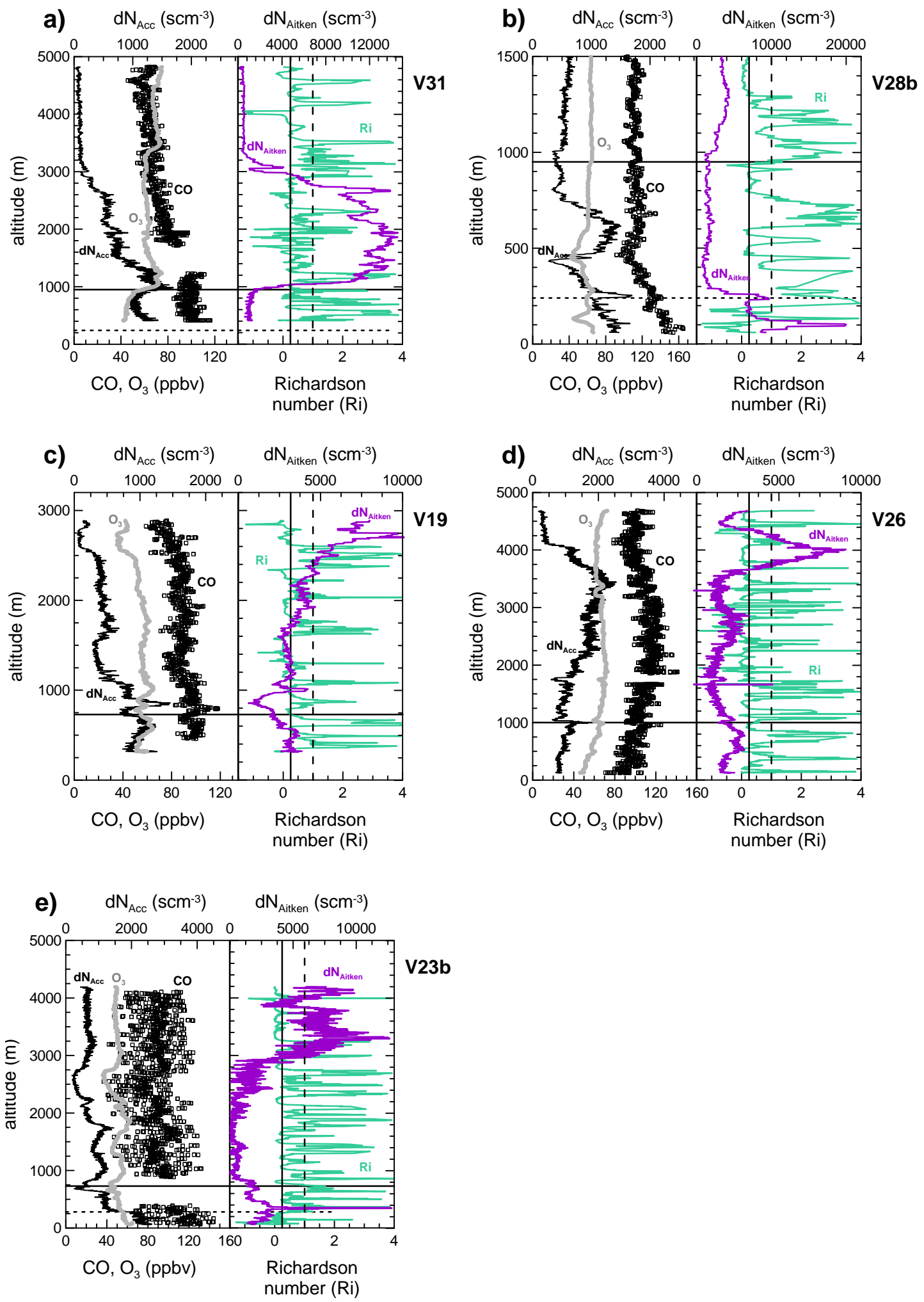

Figure 10. Vertical profiles of the accumulation and Aitken particle concentrations ( $\mathrm{d} N_{\text {Acc }}$, black line, and $\mathrm{d} N_{\text {Aitken }}$, purple line), CO (black dots), $\mathrm{O}_{3}$ (grey dots), and gradient Richardson number ( $R i$, green line) for flights (a) V31, (b) V28, (c) V19, (d) V26 and (e) V23b. The horizontal lines indicate the height of the marine boundary layer MABL (dotted line) and the planetary boundary layer BL (continuous line), while the vertical lines indicate $R i_{\text {crit }}=0.25$ and $R i=1$ (continuous and dashed lines, respectively). 
and $\mathrm{O}_{3}$, which suggests that the layer has been transported from a region directly emitting in this size range. These cases are: V16 at $\sim 200-400 \mathrm{~m}, \mathrm{~V} 21$ at $\sim 400-800 \mathrm{~m}, \mathrm{~V} 28$ at $\sim 250 \mathrm{~m}$, and V31 at $\sim 1000-3000 \mathrm{~m}$ (only V28 and V31 are shown in Fig. 10). The most remarkable example is V31 (Fig. 10a), performed close to the coast of Spain near Valencia, for which the high $\mathrm{d} N_{\text {Aitken }}$ layer extends from the top of the BL to $\sim 3000 \mathrm{~m}$ altitude. The wind vector and the backtrajectories (not shown) indicates that the air mass comes from the west-south-west above $1000 \mathrm{~m}$, so the $\mathrm{d} N_{\text {Aitken }}$ layer could be directly related to pollution export from the urban region of Valencia.

In all the other cases the high $\mathrm{d} N_{\text {Aitken }}$ layer is generally not related to simultaneous $\mathrm{d} N_{\mathrm{Acc}}$ and $\mathrm{O}_{3}$ increase. Two of these cases (V16 at $\sim 800-1000 \mathrm{~m}$ and V28 at $\sim 100 \mathrm{~m}$ ) occur in the BL.

For the V28 layer (Fig. 10b) the $\mathrm{d} N_{\text {Aitken }}$ is correlated with $\mathrm{CO}$ which might indicate the influence of local emissions close to the surface level (i.e. ship emissions). CO values are relatively high (140-160 ppbv) within the layer. It has been often assumed that new particle formation events (NPF) only occur in mostly clean environments (e.g. O'Dowd et al., 2010; Sellegri et al., 2010), and that they are suppressed under polluted conditions. In a recent study, Brines et al. (2015) also show the occurrence of NPF events in urban areas with high levels of pollution in the Mediterranean region. So, we explore the possibility of NPF in our observations. Given the size ranges of the CPC and PCASP, however, we cannot determine particle concentration within $\mathrm{d} N_{\text {Aitken }}$ in the sole 4$20 \mathrm{~nm}$ range, i.e. the size range involved in nucleation. So it is not possible to directly associate the V28 observations with NPF. In order to obtain a qualitative indication of the possible occurrence of NPF, we have looked at the air mass dynamics within the layer. Several studies suggest, in fact, that NPF might be favoured by turbulence and air mass mixing (e.g. Nilsson et al., 2001; Wehner et al., 2010). We have thus looked at the gradient Richardson number $(R i)$ which gives information on the atmospheric dynamical stability. Vertical profiles of $R i$ are also shown in Fig. 10. For V28 the vertical profile of $R i$ indicates that below $200 \mathrm{~m}$ the $R i$ number is consistently below zero, which suggests well-established turbulent conditions possibly favouring NPF in this layer.

In other two cases (V19, Fig. 10c, and V26, Fig. 10d), under lower pollution conditions $(\mathrm{CO}<100)$, we measured high $\mathrm{d} N_{\text {Aitken }}$ concentration corresponding with low $\mathrm{d} N_{\text {Acc }}$ layers in the FT at $\sim 2800-3000 \mathrm{~m}$ for V19 and $3500-4500 \mathrm{~m}$ for V26. For V19 and V26 layers, d $N_{\text {Aitken }}$ seems anticorrelated to CO. Also in this case the Richardson number is below $R i_{\text {crit }}$ corresponding with Aitken peak, meaning that conditions are favourable for turbulence within the layer, and this may indicate the possible role of NPF in this case as well.

Finally, a case of high $\mathrm{d} N_{\text {Aitken }}$ concentration has been also observed corresponding to dust particles between $\sim 3000$ and $4000 \mathrm{~m}$ (V23b, Fig. 10e). This layer can be possibly linked to the photochemically induced nucleation which may occur in the presence of dust and $\mathrm{SO}_{2}$ as hypothesised in a recent study by Dupart et al. (2012) and observed by Nie et al. (2014).

\section{Conclusions}

The data presented in this paper gives an overview of the distribution of aerosols and trace gases within the tropospheric column up to $5000 \mathrm{~m}$ above the western Mediterranean basin.

These data add to the very few available measurements of aerosol and trace gases vertical profiles over the sea surface in the central (e.g. Junkermann, 2001; Meloni et al., 2003; Di Iorio et al., 2003; Pace et al., 2015) and eastern (e.g. Formenti et al., 2002; Dulac and Chazette, 2003) parts of the basin thus improving the description of the atmospheric composition and structure over the whole Mediterranean area.

Observations from the present study indicate that continental pollution strongly affects the composition and structure of the western Mediterranean basin both close to coastal regions and in the open sea. Pollution layers extend up to $250 \mathrm{~km}$ far from the coast and reach up to $3000-4000 \mathrm{~m}$ altitude, presenting a complex and highly stratified structure. The measured particle concentration is comparable with the values reported for continental Europe (Petzold et al., 2002; Junkermann, 2009; Hamburger et al., 2012).

Pollution plumes with different compositions, origins, and lifetimes are observed in relation to the different observed dynamical export conditions and meteorological regimes. The aerosol and trace gas observations during TRAQA and SAFMED are consistent with the results of previous campaigns and with the interpretation of observed or well-known air mass dynamics and meteorological phenomena that occur in the western basin (Flamant and Pelon, 1996; Millan et al., 1997; Gangoiti et al., 2001; Pérez et al., 2004; Mallet et al., 2005).

The large heterogeneity in aerosol compositions, origins, and lifetimes as documented in this study can reflect a large heterogeneity of aerosol optical properties, with consequences for their direct radiative effect in this part of the basin. This will be investigated in a companion paper analysing the TRAQA and SAFMED in situ measurements of the aerosol absorption and scattering properties and their variability.

From the present observations, it is also worth noting the relatively high values of $\mathrm{d} N_{\text {Aitken }}$ measured both in the BL and the FT, which evidences the important contribution of ultrafine particles at all altitudes over the basin. These could be linked to the different export mechanisms previously discussed and the possible occurrence of NPF events. Aitken particle profiles are very rare over the sea surface in the Mediterranean (e.g. Junkermann et al., 2001; Pace et al., 2015) and data comparison is quite difficult. A few studies have observed NPF in the FT in continental areas (Boulon et al., 2010; Rose et al., 2015) and suggest that the export 
of pollution into the upper troposphere, as is common in the western basin, might promote the occurrence of these events. The observations of the present study may thus also have very large implications due to the crucial role of NPF in controlling the atmospheric cloud condensation nuclei concentration (Spracklen et al., 2008) and the associated aerosol indirect effect on climate.

Author contributions. J.-L. Attié, F. Ravetta, G. Ancellet, M. Beekmann, A. Borbon, P. Formenti and K. Sartelet designed the TRAQA and SAFMED experiments and coordinated the campaigns. C. Gaimoz, N. Grand, and C. Di Biagio operated the instruments on board the ATR-42 during the flights. C. Di Biagio performed data analysis with contributions from L. Doppler, P. Formenti, F. Ravetta, A. Borbon, G. Ancellet, J.-C. Raut, and M. Beekmann. G. Ancellet performed FLEXTRA simulations. J.-C.R. performed WRF-Chem simulations. C. Di Biagio wrote the manuscript.

Acknowledgements. All measurement presented here are from the Chemistry-Aerosol Mediterranean Experiment project (ChArMEx, http://charmex.lsce.ipsl.fr), which is the atmospheric component of the French multidisplinary program MISTRALS (Mediterranean Integrated Studies aT Regional And Local Scales). ChArMExFrance was principally funded by INSU, ADEME, ANR, CNES, CTC (Corsica region), EU/FEDER, Météo-France, and CEA. TRAQA was funded by ADEME/PRIMEQUAL and MISTRALS/ChArMEx programmes and Observatoire Midi-Pyrénées. SAFMED was funded by the ANR project SAF-MED (Secondary Aerosol Formation in the MEDiterranean, grant SIMI6 ANR-12BS06-0013). C. Di Biagio thanks the Centre National des Etudes Spatiales (CNES) for financial support.

The authors wish to thank the technicians, pilots and ground crew of SAFIRE (Service des Avions Francais Instruments pour la Recherche en Environnement) for facilitating the instrument integration and conducting flying operations. We thank S. Chevaillier, L. Girault, R. Loisil, J. Pelon, S. Triquet, and P. Zapf for their contribution during the campaigns. We thank S. Basart, J. M. Baldasano, M. Mallet, P. Goloub, J. Piazzola and their staff for establishing and maintaining the Barcelona, Ersa, and Frioul AERONET sites. Helpful discussions with G. Pace are gratefully acknowledged. We thank also two anonymous reviewers whose suggestions helped to clarify the manuscript.

Edited by: C. Reeves

\section{References}

Ancellet, G. and Ravetta, F.: Analysis and validation of ozone variability observed by lidar during the ESCOMPTE-2001 campaign, Atmos. Res., 74, 435-459, 2005.

Anderson, T. L. and Ogren, J. A.: Determining aerosol radiative properties using the TSI 3563 integrating nephelometer, Aerosol Sci. Technol., 29, 57-69, 1998.

Anderson, T. L., Covert, D. S., Marshall, S. F., Laucks, M. L., Charlson, R. J., Waggoner, A. P., Ogren, J. A., Caldow, R., Holm, R. L.,
Quant, F. R., Sem, G. J., Wiedensholer, A., Ahlquist, N. A., and Bates, T. S.: Performance characteristics of a high-sensitivity, three-wavelength, total scatter/backscatter nephelometer, J. Atmos. Ocean. Tech., 13, 967-986, 1996.

Bonasoni, P., Cristofanelli, P., Calzolari, F., Bonafè, U., Evangelisti, F., Stohl, A., Zauli Sajani, S., van Dingenen, R., Colombo, T., and Balkanski, Y.: Aerosol-ozone correlations during dust transport episodes, Atmos. Chem. Phys., 4, 1201-1215, doi:10.5194/acp4-1201-2004, 2004.

Boucher, O., Randall, D., Artaxo, P., Bretherton, C., Feingold, G., Forster, P., Kerminen, V.-M., Kondo, Y., Liao, H., Lohmann, U., Rasch, P., Satheesh, S. K., Sherwood, S., Stevens, B., and Zhang, X. Y.: Clouds and Aerosols, in: Climate Change 2013: The Physical Science Basis. Contribution of Working Group I to the Fifth Assessment Report of the Intergovernmental Panel on Climate Change, edited by: Stocker, T. F., Qin, D., Plattner, G.-K., Tignor, M., Allen, S. K., Boschung, J., Nauels, A., Xia, Y., Bex, V., and Midgley, P. M., Cambridge University Press, Cambridge, United Kingdom and New York, NY, USA, 571-657, 2013.

Boulon, J., Sellegri, K., Venzac, H., Picard, D., Weingartner, E., Wehrle, G., Collaud Coen, M., Bütikofer, R., Flückiger, E., Baltensperger, U., and Laj, P.: New particle formation and ultrafine charged aerosol climatology at a high altitude site in the Alps (Jungfraujoch, $3580 \mathrm{~m}$ a.s.1., Switzerland), Atmos. Chem. Phys., 10, 9333-9349, doi:10.5194/acp-10-9333-2010, 2010.

Brines, M., Dall'Osto, M., Beddows, D. C. S., Harrison, R. M., Gómez-Moreno, F., Níñez, L., Artíñano, B., Costabile, F., Gobbi, G. P., Salimi, F., Morawska, L., Sioutas, C., and Querol, X.: Traffic and nucleation events as main sources of ultrafine particles in high-insolation developed world cities, Atmos. Chem. Phys., 15, 5929-5945, doi:10.5194/acp-15-5929-2015, 2015.

Chazette, P., Randriamiarisoa, H., Sanak, J., Couvert, P., and Flamant, C.: Optical properties of urban aerosol from airborne and ground based in situ measurements performed during the ESQUIF program, J. Geophys. Res., 110, D02206, doi:10.1029/2004JD004810, 2005.

Chin, M., Jacob, D. J., Munger, J. W., Parrish, D. D., and Doddridge, B. G.: Relationship of ozone and carbon monoxide over North America, J. Geophys. Res., 99, 14565-14573, 1994.

Cristofanelli, P., Fierli, F., Marinoni, A., Calzolari, F., Duchi, R., Burkhart, J., Stohl, A., Maione, M., Arduini, J., and Bonasoni, P.: Influence of biomass burning and anthropogenic emissions on ozone, carbon monoxide and black carbon at the Mt. Cimone GAW-WMO global station (Italy, $2165 \mathrm{~m}$ a.s.l.), Atmos. Chem. Phys., 13, 15-30, doi:10.5194/acp-13-15-2013, 2013.

Di Iorio, T., di Sarra, A., Junkermann, W., Cacciani, M., Fiocco, G., and Fua', D.: Tropospheric aerosols in the Mediterranean: 1. Microphysical and optical properties, J. Geophys. Res., 108, 4316, doi:10.1029/2002JD002815, 2003.

Drobinski, P, Saïd, F., Ancellet, G., Arteta, J. Augustin, P., Bastin, S., Brut, A., Caccia, J. L., Campistron, B., Cautenet, S., Colette, A., Coll, I., Corsmeier, U., Cros, B., Dabas, A., Delbarre, H., Dufour, A., Durand, P., Guénard, V., Hasel, M., Kalthoff, N., Kottmeier, C., Lasry, F., Lemonsu, A., Lohou, F., Masson, V., Menut, L., Moppert, C., Peuch, V. H., Puygrenier, V., Reitebuch, O., and Vautard, R.: Regional transport and dilution during highpollution episodes in southern France: Summary of findings from the Field Experiment to Constraint Models of Atmospheric Pol- 
lution and Emissions Transport (ESCOMPTE), J. Geophys. Res., 112, D13105, doi:10.1029/2006JD007494, 2007.

Dulac, F. and Chazette, P.: Airborne study of a multi-layer aerosol structure in the eastern Mediterranean observed with the airborne polarized lidar ALEX during a STAAARTE campaign (7 June 1997), Atmos. Chem. Phys., 3, 1817-1831, doi:10.5194/acp-31817-2003, 2003.

Dupart, Y., King, S. M., Nekat, B., Nowak, A., Wiedensohler, A., Herrmann, H., David, G., Thomas, B., Miffre, A., Rairoux, P., D'Anna, B., and George, C.: Mineral dust photochemistry induces nucleation events in the presence of $\mathrm{SO}_{2}$, Proc. Natl. Aca. Sci., 109, 20842-20847, 2012.

Ebert, M., Weinbruch, S., Rausch, A., Gorzawski, G., Hoffmann, P., Wex, H., and Helas, G.: The complex refractive index of aerosols during LACE 98 as derived from the analysis of individual particles, J. Geophys. Res., 107, 8121, doi:10.1029/2000JD000195, 2002.

Ebert, M., Weinbruch, S., Hoffmann, P., and Ortner, H. M.: The chemical composition and complex refractive index of rural and urban influenced aerosols determined by individual particle analysis, Atmos. Environ., 38, 6531-6545, 2004.

Flamant, C. and Pelon, J.: Atmospheric boundary-layer structure over the Mediterranean during a Tramontane event, Quart. J. Roy. Meteorol. Soc., 122, 1741-1778, 1996.

Formenti, P., Reiner, T., Sprung, D., Andreae, M. O., Wendisch, M., Wex, H., Kindred, D., Dewey, K., Kent, J., Tzortziou, M., Vasaras, A., and Zerefos, C.: STAAARTE-MED 1998 summer airborne measurements over the Aegean Sea, 1, Aerosol particles and trace gases, J. Geophys. Res., 107, 4450, doi:10.1029/2001JD001337, 2002.

Formenti, P., Rajot, J. L., Desboeufs, K., Saïd, F., Grand, N., Chevaillier, S., and Schmechtig, C.: Airborne observations of mineral dust over western Africa in the summer Monsoon season: spatial and vertical variability of physico-chemical and optical properties, Atmos. Chem. Phys., 11, 6387-6410, doi:10.5194/acp-11-6387-2011, 2011.

Gangoiti, G., Millán, M. M., Salvador, R., and Mantilla, E.: LongRange transport and recirculation of pollutants in the Western Mediterranean during the RECAPMA Project. Atmos. Environ., 35, 6267-6276, 2001.

Gkikas, A., Houssos, E. E., Hatzianastassiou, N., Papadimas, C. D., and Bartzokas, A.: Synoptic conditions favouring the occurrence of aerosol episodes over the broader Mediterranean basin, Q. J. R. Meteorol. Soc., 138, 932-949, doi:10.1002/qj.978, 2012.

Grell, G. A., Peckham, S. E., Schmitz, R., McKeen, S. A., Frost, G., Skamarock, W. C., and Eder, B.: Fully coupled "online" chemistry within the WRF model, Atmos. Environ., 39, 6957-6975, 2005.

Hamburger, T., McMeeking, G., Minikin, A., Petzold, A., Coe, H., and Krejci, R.: Airborne observations of aerosol microphysical properties and particle ageing processes in the troposphere above Europe, Atmos. Chem. Phys., 12, 11533-11554, doi:10.5194/acp-12-11533-2012, 2012.

Haywood, J., Johnson, B., Osborne, S., Mulcahy, J., Brooks, M., Harrison, M., Milton, S., and Brindley, H.: Observations and modelling of the solar and terrestrial radiative effects of Saharan dust: a radiative closure case-study over oceans during the GERBILS campaign, Q. J. R. Meteorol. Soc., 137, 1211-1226, doi:10.1002/qj.770, 2011.
Highwood, E. J., Northway, M. J., McMeeking, G. R., Morgan, W. T., Liu, D., Osborne, S., Bower, K., Coe, H., Ryder, C., and Williams, P.: Aerosol scattering and absorption during the EUCAARI-LONGREX flights of the Facility for Airborne Atmospheric Measurements (FAAM) BAe-146: can measurements and models agree?, Atmos. Chem. Phys., 12, 7251-7267, doi:10.5194/acp-12-7251-2012, 2012.

Holben, B. N., Eck, T. F, Slutsker, I., Tanré, D., Buis, J. P., Setzer, A., Vermote, E., Reagan, J. A., Kaufman, Y., Nakajima, T., Lavenu, F., Jankowiak, I., and Smirnov, A.: AERONET: a federated instrument network and data archive for aerosol characterization, Remote Sens. Environ., 66, 1-16, 1998.

Jiménez, P., Lelieveld, J., and Baldasano, J. M.: Multiscale modeling of air pollutants dynamics in the northwestern Mediterranean basin during a typical summertime episode, J. Geophys. Res., 111, D18306, doi:10.1029/2005JD006516, 2006.

Jiménez-Guerrero, P., Jorba, O., Baldasano, J. M., and Gassó, S.: The use of a modelling system as a tool for air quality management: Annual high-resolution simulations and evaluation, Sci. Total Environ., 390, 323-340, 2008.

Junkermann, W.: An ultralight aircraft as platform for research in the lower troposphere: System performance and first results from radiation transfer studies in stratiform aerosol layers and broken cloud conditions, J. Atmos. Oceanic Technol., 18, 934-946, 2001.

Junkermann, W.: On the distribution of formaldehyde in the western Po-Valley, Italy, during FORMAT 2002/2003, Atmos. Chem. Phys., 9, 9187-9196, doi:10.5194/acp-9-9187-2009, 2009.

Kaiser, J., Wolfe, G. M., Bohn, B., Broch, S., Fuchs, H., Ganzeveld, L. N., Gomm, S., Häseler, R., Hofzumahaus, A., Holland, F., Jäger, J., Li, X., Lohse, I., Lu, K., Prévôt, A. S. H., Rohrer, F., Wegener, R., Wolf, R., Mentel, T. F., Kiendler-Scharr, A., Wahner, A., and Keutsch, F. N.: Evidence for an unidentified non-photochemical ground-level source of formaldehyde in the Po Valley with potential implications for ozone production, Atmos. Chem. Phys., 15, 1289-1298, doi:10.5194/acp-15-12892015, 2015.

Kallos, G., Astitha, M., Katsafados, P., and Spyrou, C.: Long-range transport of anthropogenically and naturally produced particulate matter in the Mediterranean and North Atlantic: Current state of knowledge, J. Appl. Meteorol. Climatol., 46, 1230-1251, 2007.

Kulmala, M., Vehkamaki, H., Petaja, T., Dal Maso, M., Lauri, A., Kerminen, V.-M., Birmili, W., and McMurry, P.H.: Formation and growth rates of ultrafine atmospheric particles: A review of observations, J. Aerosol Sci., 35, 143-176, 2004.

Lelieveld, J., Berresheim, H., Borrmann, S., Crutzen, P. J., Dentener, F. J., Fischer, H., Feichter, J., Flatau, P. J., Heland, J., Holzinger, R., Korrmann, R., Lawrence, M. G., Levin, Z., Markowicz, K. M., Mihalopoulos, N.; Minikin, A., Ramanathan, V., de Reus, M., Roelofs, G. J., Scheeren, H. A., Sciare, J., Schlager, H., Schultz, M., Siegmund, P., Steil, B., Stephanou, E. G., Stier, P., Traub, M., Warneke, C., Williams, J., and Ziereis H.: Global air pollution crossroads over the Mediterranean, Science, 298, 794-799, doi:10.1126/science.1075457, 2002.

Liu, Y. and Daum, P.: The effect of refractive index on size distributions and light scattering coefficients derived from optical particle counters, J. Aerosol Sci., 31, 945-957, 2000. 
Mallet, M., Roger, J. C., Despiau, S., Dubovik, O., and Putaud, J. P.: Microphysical and optical properties of aerosol particles in urban zone during ESCOMPTE, Atmos. Res., 69, 73-97, 152003.

Mallet, M., Van Dingenen, R., Roger, J. C., Despiau, S., and Cachier, H.: In situ airborne measurements of aerosol optical properties during photochemical pollution events, J. Geophys. Res., 110, D03205, doi:10.1029/2004JD005139, 2005.

Mallet, M., Gomes, L., Solmon, F., Sellegri, K., Pont, V., Roger, J. C., Missamou, T., and Piazzola, J.: Calculation of key optical properties of the main anthropogenic aerosols over the Western French coastal Mediterranean Sea, Atmos. Res., 101, 396-411, 2011.

Meloni, D., di Sarra, A., DeLuisi, J., Di Iorio, T., Fiocco, G., Junkermann, W., and Pace, G.: Tropospheric aerosols in the Mediterranean: 2. Radiative effects through model simulations and measurements, J. Geophys. Res., 108, 4317, doi:10.1029/2002JD002807, 2003.

Millán, M., Salvador, R., Mantilla, E., and Artinãno, B.: Meteorology and photochemical air pollution in Southern Europe: experimental results from EC research projects, Atmos. Environ., 30, 1909-1924, 1996.

Millán, M. M., Salvador, R., Mantilla, E., and Kallos, G.: Photooxidant dynamics in the Western Mediterranean in summer: Results from European research projects, J. Geophys. Res., 102, 88118823, 1997.

Millán, M. M., Mantilla, E., Salvador, R., Carratala, A., Sanz, M. J., Alonso, L., Gangoiti, G., and Navazo, M.: Ozone cycles in the western Mediterranean basin: interpretation of monitoring data in complex terrain, J. Appl. Meteorol., 4, 487-507, 2000.

Monks, P., Granier, C., Fuzzi, S., Stohl, A., Williams, M., Akimoto, H., Amann, M., Baklanov, A., Baltensperger, U., Bey, I., Blake, N., Blake, R., Carslaw, K., Cooper, O., Dentener, F., Fowler, D., Fragkou, E., Frost, G., Generoso, S., Ginoux, P., Grewe, V., Guenther, A., Hansson, H., Henne, S., Hjorth, J., Hofzumahaus, A., Huntrieser, H., Isaksen, I., Jenkin, M., Kaiser, J., Kanakidou, M., Klimont, Z., Kulmala, M., Laj, P., Lawrence, M., Lee, J., Liousse, C., Maione, M., McFiggans, G., Metzger, A., Mieville, A., Moussiopoulos, N., Orlando, J., O’Dowd, C., Palmer, P., Parrish, D., Petzold, A., Platt, U., Pöschl, U., Prévôt, A., Reeves, C., Reimann, S., Rudich, Y., Sellegri, K., Steinbrecher, R., Simpson, D., ten Brink, H., Theloke, J., van der Werf, G., Vautard, R., Vestreng, V., Vlachokostas, C., and von Glasow, R.: Atmospheric composition change - global and regional air quality, Atmos. Environ., 43, 5268-5350, doi:10.1016/j.atmosenv.2009.08.021, 2009.

Müller, D., Ansmann, A., Wagner, F., Franke, K., and Althausen, D.: European pollution outbreaks during ACE 2: Microphysical particle properties and single-scattering albedo inferred from multiwavelength lidar observations, J. Geophys. Res., 107, 4248, doi:10.1029/2001JD001110, 2002.

Nedelec, P., Cammas, J.-P., Thouret, V., Athier, G., Cousin, J.-M., Legrand, C., Abonnel, C., Lecoeur, F., Cayez, G., and Marizy, C.: An improved infrared carbon monoxide analyser for routine measurements aboard commercial Airbus aircraft: technical validation and first scientific results of the MOZAIC III programme, Atmos. Chem. Phys., 3, 1551-1564, doi:10.5194/acp-3-15512003, 2003.

Nie, W., Ding, A., Wang, T., Kerminen, V.-M., George, C., Xue, L., Wang, W., Zhang, Q., Petaja, T., Qi, X., Gao, X., Wang,
X., Yang, X., Fu, C., and Kulmala, M.: Polluted dust promotes new particle formation and growth, Sci. Rep., 4, 6634, doi:10.1038/srep06634, 2014.

Nilsson, E. D., Rannik, U., Kulmala, M., Buzorius, G., and, O'Dowd, C. D.: Effects of continental boundary layer evolution, convection, turbulence and entrainment, on aerosol formation, Tellus B, 53, 441-461, 2001.

O’Dowd, C., Monahan, C., and Dall'Osto, M.: On the occurrence of open ocean particle production and growth events, Geophys. Res. Lett., 37, L19805, doi:10.1029/2010GL044679, 2010.

Pace, G., di Sarra, A., Meloni, D., Piacentino, S., and Chamard, P.: Aerosol optical properties at Lampedusa (Central Mediterranean). 1. Influence of transport and identification of different aerosol types, Atmos. Chem. Phys., 6, 697-713, doi:10.5194/acp-6-697-2006, 2006.

Pace, G., Junkermann, W., Vitali, L., di Sarra, A., Meloni, D., Cacciani, M., Cremona, G., Iannarelli, A. M., and Zanini, G.: On the complexity of the boundary layer structure and aerosol vertical distribution in the coastal Mediterranean regions: a sea breeze, desert dust transport, and free-tropospheric air intrusion case study in Southern, Tellus B, submitted, 2015.

Parrish, D. D., Holloway, J. S., Trainer, M., Murphy, P. C., Fehsenfeld, F. C., and Forbes, G. L.: Export of North America ozone pollution to the North Atlantic Ocean, Science, 259, 1436-1439, 1993.

Parrish, D. D., Trainer, M., Holloway, J. S., Yee, J. E., Warshawsky, M. S., Fehsenfeld, F. C., Forbes, G. L., and Moody, J. L.: Relationships between ozone and carbon monoxide at surface sites in the North Atlantic region, J. Geophys. Res., 103, 13357-13376, 1998.

Pérez, C., Sicard, M., Jorba, O., Comeron, A., and Baldasano, J. M.: Summertime re-recirculations of air pollutants over the NorthEastern Iberian coast observed from systematic EARLINET lidar measurements in Barcelona, Atmos. Environ., 38, 3983-4000, 2004.

Pérez, N., Pey, J., Castillo, S., Viana, M., Alastuey, A., and Querol, $\mathrm{X}$.: Interpretation of the variability of levels of regional background aerosols in the Western Mediterranean, Sci. Tot. Environ., 407, 527-540, 2008.

Petzold, A., Fiebig, M., Flentje, H., Keil, A., Leiterer, U., Schroder, F., Stifter, A., Wendisch, M., and Wendling, P.: Vertical variability of aerosol properties observed at a continental site during the Lindenberg Aerosol Characterization Experiment (LACE 98), J Geophys. Res., 107, 8128, doi:10.1029/2001JD001043, 2002.

Pey, J., Querol, X., and Alastuey, A.: Discriminating the regional and urban contributions in the North-Western Mediterranean: PM levels and composition, Atmos. Environ., 44, 1587-96, 2010.

Raut, J.-C. and Chazette, P.: Vertical profiles of urban aerosol complex refractive index in the frame of ESQUIF airborne measurements, Atmos. Chem. Phys., 8, 901-919, doi:10.5194/acp-8-9012008, 2008.

Rose, C., Sellegri, K., Asmi, E., Hervo, M., Freney, E., Colomb, A., Junninen, H., Duplissy, J., Sipilä, M., Kontkanen, J., Lehtipalo, K., and Kulmala, M.: Major contribution of neutral clusters to new particle formation at the interface between the boundary layer and the free troposphere, Atmos. Chem. Phys., 15, 34133428, doi:10.5194/acp-15-3413-2015, 2015.

Salameh, T., Drobinski, P., Menut, L., Bessagnet, B., Flamant, C., Hodzic, A., and Vautard, R.: Aerosol distribution over the 
western Mediterranean basin during a Tramontane/Mistral event, Ann. Geophys., 25, 2271-2291, doi:10.5194/angeo-25-22712007, 2007.

Sellegri, K., Laj, P., Venzac, H., Boulon, J., Picard, D., Villani, P., Bonasoni, P., Marinoni, A., Cristofanelli, P., and Vuillermoz, E.: Seasonal variations of aerosol size distributions based on longterm measurements at the high altitude Himalayan site of Nepal Climate Observatory-Pyramid (5079 m), Nepal, Atmos. Chem. Phys., 10, 10679-10690, doi:10.5194/acp-10-10679-2010, 2010.

Soriano, C., Baldasano, J. M., Buttler, W. T., and Moore, K.: Circulatory patterns of air pollutants within the Barcelona air basin in a summertime situation: lidar and numerical approaches, Bound.Lay. Meteorol., 98, 33-55, 2001.

Spracklen, D. V., Carslaw, K. S., Kulmala, M., Kerminen, V.-M., Sihto, S.-L., Riipinen, I., Merikanto, J., Mann, G. W., Chipperfield, M. P., and Wiedensohler, A.: Contribution of particle formation to global cloud condensation nuclei concentrations, Geophys. Res. Lett., 35, L06808, doi:10.1029/2007GL033038, 2008.

Stohl, A., Wotawa, G., Seibert, P., and Krompkolb, H.: Interpolation errors in wind fields as a function of spatial and temporal resoloution and their impact on different types of kinematic trajectories, J. Appl. Meteorol., 34, 2149-2165, 1995.
Velchev, K., Cavalli, F., Hjorth, J., Marmer, E., Vignati, E., Dentener, F., and Raes, F.: Ozone over the Western Mediterranean Sea - results from two years of shipborne measurements, Atmos. Chem. Phys., 11, 675-688, doi:10.5194/acp-11-675-2011, 2011.

Wallace, J. M. and Hobbs, P. V.: Atmospheric science: an introductory survey, 2nd Edn., International Geophysics Series 92, Academic press, Burlington, 484 pp., 2006.

Wehner, B., Siebert, H., Ansmann, A., Ditas, F., Seifert, P., Stratmann, F., Wiedensohler, A., Apituley, A., Shaw, R. A., Manninen, H. E., and Kulmala, M.: Observations of turbulence-induced new particle formation in the residual layer, Atmos. Chem. Phys., 10, 4319-4330, doi:10.5194/acp-10-4319-2010, 2010.

Wiegner, M., Emeis, S., Freudenthaler, V., Heese, B., Junkermann, W., Münkel, C., Schäfer, K., Seefeldner, M., and Vogt, S.: Mixing layer height over Munich, Germany: variability and comparisons of different methodologies, J. Geophys. Res., 111, D13201, doi:10.1029/2005JD006593, 2006.

Zhang, L., Jacob, D. J., Bowman, K. W., Logan, J. A., Turquety, S., Hudman, R. C., Li, Q., Beer, R., Worden, H. M., Worden, J. R., Rinsland, C. P., Kulawik, S. S., Lampel, M. C., Shephard, M. W., Fisher, B. M., Eldering, A., and Avery M. A.: Ozone$\mathrm{CO}$ correlations determined by the TES satellite instrument in continental outflow regions, Geophys. Res. Lett., 33, L18804, doi:10.1029/2006GL026399, 2006. 